\title{
Phenotypic Properties of Catecholamine-Positive Cells That Differentiate in Avian Neural Crest Cultures
}

\author{
Douglas S. Christie, ${ }^{a}$ M. Elizabeth Forbes, and Gerald D. Maxwell \\ Department of Anatomy, University of Connecticut Health Center, Farmington, Connecticut 06032
}

We have investigated several phenotypic features of the catecholamine-positive $(\mathrm{CA}+)$ cell population that develops in quail neural crest cultures. The number, spatial distribution, and morphology of CA + and tyrosine hydroxylase-positive $(\mathrm{TH}+)$ cells are similar at all ages examined, suggesting that these 2 cell classes are identical. Neither CA + nor TH+ cell bodies or processes were stained using antisera that recognize the 70 or $160 \mathrm{kDa}$ subunits of chicken neurofilament protein. Other cell bodies and fibers in the cultures (which were $\mathrm{CA}-$ and $\mathrm{TH}-$ ) were stained with these neurofilament antisera. The uptake and storage of ${ }^{3} \mathrm{H}-$ norepinephrine by neural crest cultures containing CA + cells were inhibited in the presence of desmethylimipramine and by incubation at $0^{\circ} \mathrm{C}$, but were unaffected by normetanephrine. Overnight treatment with reserpine eliminated histochemically detectable CA fluorescence from the cultures. Chronic reserpine treatment from day 2 to 7 in vitro prevented the appearance of CA + cells, while normal numbers of TH+ and somatostatin-like immunoreactive (SLI) cells developed. The number and light-microscopic morphology of the CA+ cells that developed in these cultures were not dramatically altered by either exogenous NGF or 6-hydroxydopamine. Using the method of Grillo et al. (1974), we have demonstrated that the CA + cells observed in the light microscope corresponded to cells containing abundant cytoplasmic granular vesicles (GV) characteristic of catecholamine storage granules observed in other systems. The GV diameters were quite similar in cells examined after 5, 7, 14, and $21 \mathrm{~d}$ in vitro. Most GV were $50-200 \mathrm{~nm}$ in diameter and were distributed in a unimodal manner, with the observed modal values in the range of $85-115 \mathrm{~nm}$ at the ages examined. The number of $\mathrm{GV} / \mu \mathrm{m}^{2}$ of cytoplasmic area remained quite constant at all ages examined. These data, taken together with other available information, suggest that the CA+ cells that differentiate in our neural crest cultures resemble, in many respects, the small, intensely fluorescent cells found in autonomic ganglia and extra-adrenal chromatfin tissue of many species. At present, we do not know if the CA+cells that

\footnotetext{
Received Feb. 11, 1987; revised May 7, 1987; accepted May 14, 1987.

This work was supported by NIH Grants NS16115, Research Career Development Award NS00696 (G.D.M.), and NRSA NS 17841 (D.S.C.). We would like to thank Drs. Gudrun Bennett, Hiroshi Hatanaka, and Bill Tank for their generous gifts of antibodies, Dr. Doug Oliver for the use of his equipment and helpful discussions, and Dr. Michael Rosenberg for performing the NGF RIA determinations and commenting on the manuscript.

Correspondence should be addressed to Dr. Gerald D. Maxwell at the above address.

a Present address: Anatomy and Physiology Branch, Medicine and Surgery Division, Academy of Health Sciences, Fort Sam Houston, TX 78234-6100.
}

Copyright (C) 1987 Society for Neuroscience $0270-6474 / 87 / 113749-15 \$ 02.00 / 0$ differentiate in our neural crest cultures are a stable endpoint of development or whether they are a developmental intermediate in adrenergic differentiation that is normally observed only transiently during the development of avian sympathetic ganglia in vivo, but that can persist under our tissue culture conditions.

The embryonic neural crest is the source of the progenitor cells that migrate, proliferate, and differentiate to form most of the peripheral nervous system, including the neurons of the sympathetic, parasympathetic, enteric, and most sensory ganglia (Weston, 1970; Noden, 1978; LeDouarin, 1982). In addition, neural crest cells are the sourcc of many other cell types, including the cells of the adrenal medulla, Schwann cells, melanocytes, and skeletal and connective tissue of the head and face. We have been studying the neuronal differentiation of neural crest cells in tissue culture, with particular emphasis on those cells that develop adrenergic properties.

During embryonic development, neural crest cells acquire particular differentiated traits that can be used as phenotypic markers of their maturation into neurons. One such marker is the acquisition of the capacity to metabolize specific neurotransmitter compounds. A subset of neural crest cells grown in tissue culture develops into cells with the capacity to synthesize, store, take up, and release catecholamines (CA) (Cohen, 1977; Sieber-Blum and Cohen, 1980; Fauquet et al., 1981; Maxwell et al., 1982; Maxwell and Sietz, 1983, 1985). Some of these neural crest cells that become $\mathrm{CA}+$ also develop somatostatinlike immunoreactivity (SLI) (Maxwell et al., 1984a; Sieber-Blum, 1984). This differentiation of neural crest cells in tissue culture parallels in many respects their development in vivo. In avian embryos, CA and SLI appear in neural crest cells shortly after they have ceased their initial migration and coalesced to form the primary sympathetic trunks (Enemar et al., 1965; Kirby and Gilmore, 1976; Rothman et al., 1978; Garcia-Arraras et al., 1984; Maxwell et al., 1984b).

While the presence of CA is a useful phenotypic marker, it is not sufficient for specifying precisely what type of CA-containing cell is present (Black, 1982). There are 3 major classes of CAcontaining cells derived from the neural crest that are found in adult animals. These are principal sympathetic neurons, small, intensely fluorescent (SIF) cells, and the chromaffin cells of the adrenal medulla. In addition, $\mathrm{CA}+$ cells derived from the neural crest are found in the carotid body and in paraganglia located in various sites (Biscoe, 1971; Mascorro and Yates, 1980). Also, in some species a small population of $\mathrm{CA}+$ cells may exist in adult sensory ganglia (Price and Mudge, 1983). During embryonic development, transient $\mathrm{CA}+$ cells are present in the gut 
and dorsal root ganglia of rat and mouse embryos (Cochard et al., 1978, 1979; Teitelman et al., 1978, 1979; Jonakait et al., 1984). Although principal neurons, SIF cells, and chromaffin cells all contain $\mathrm{CA}$, they exhibit very significant differences in terms of their structures, responses to growth factors and hormones, and physiological functions. One major difference is the type and distribution of CA storage granules. In principal neurons, CA storage granules are about $50 \mathrm{~nm}$ in diameter, are found almost exclusively in cellular processes, and are virtually absent from the cell body (Grillo, 1966; Burnstock and Costa, 1975; Gabella, 1976). In SIF cells and chromaffin cells, the CA storage granules are larger and are abundant in cell bodies (Eranko, 1975). SIF cells and chromaffin cells can be further distinguished from each other by the size of the CA storage vesicles and the presence of processes in some SIF cells (Coupland, 1965; Grillo, 1966; Taxi, 1979; Taxi et al., 1983). A second difference is in the response of these cell types to growth factors and hormoncs. During cmbryonic development, principal sympathetic neurons require NGF for their survival and differentiation (LeviMontalcini and Angeletti, 1968; Greene and Shooter, 1980; Thoenen and Barde, 1980). Adrenal chromaffin cells and SIF cells show dramatic responses to glucocorticoid hormones with respect to survival and differentiation (Doupe and Patterson, 1980). However, in addition, both SIF cells and adrenal chromaffin cells from neonatal rats can be influenced by NGF to acquire principal neuron-like traits (Unsicker et al., 1978; Anderson and Axel, 1985; Doupe et al., 1985a, b).

In the present paper we have analyzed several properties of the $\mathrm{CA}+$ cells that develop in neural crest cultures in light of the known properties of CA + neural crest-derived cells in vivo. We wished to determine in some detail the extent and nature of the differentiation of the $\mathrm{CA}+$ cells that develop in our neural crest cultures. Our results suggest that the $\mathrm{CA}+$ cells that develop in our neural crest cultures possess a phenotype intermediate between that of principal sympathetic neurons and adrenal chromaffin cells, and resembles in many respects SIF cells that are found in autonomic ganglia and extra-adrenal chromaffin tissue of many species. The data presented here provide a more detailed description of the phenotypic properties of the $\mathrm{CA}+$ cells that arise in neural crest cultures than has been available previously. This information should prove useful in our analysis of how activation of the CA phenotype occurs in some neural crest cells, but not in others, during embryogenesis.

Portions of this work were presented at the 16th Annual Meeting of the Society for Neuroscience (Maxwell and Christie, 1986).

\section{Materials and Methods}

Neural crest cultures. Cultures of neural crest cells were prepared from the trunk region of embryonic day 2, stage 13 (Zacchei, 1961) Japanese quail embryos (Coturnix coturnix) and grown as described previously (Maxwell et al., 1982), with the minor modifications described below. Briefly, neural tubes containing the neural crest were isolated from surrounding tissues and were plated and grown in a medium containing $37.5 \mathrm{ml}$ Dulbecco's modified Eagle's medium with $4.5 \mathrm{gm} /$ liter glucose, pH 7.4 (Gibco), $37.5 \mathrm{ml} \mathrm{F}-12$, pH 7.4 (Gibco), $15 \mathrm{ml}$ horse serum (Gibco), $10 \mathrm{ml} 9 \mathrm{~d}$ chick embryo extract (Cahn et al., 1967), $10 \mathrm{mg}$ gentamycin sulfate (Schering), $10 \mathrm{mg}$ kanamycin sulfate (Gibco), $1 \mathrm{ml}$ of $0.2 \mathrm{M}$ L-glutamine (Sigma), and $1 \mathrm{ml}$ of $100 \times$ stock vitamin mix. Horse serum was heat-inactivated at $56^{\circ} \mathrm{C}$ for $60 \mathrm{~min}$ before use. Vitamin mix stock contained $1 \mathrm{mg}$ dimethyltetrahydrobiopterin (Calbiochem), $100 \mathrm{mg}$ ascorbic acid (Sigma), $10 \mathrm{mg}$ glutathione (Sigma), and $20 \mathrm{ml}$ distilled water, final pH 6.0 (Mains and Patterson, 1973). Cultures were grown at $36.5^{\circ} \mathrm{C}$ in a $5 \% \mathrm{CO}_{2}$ atmosphere in $35 \mathrm{~mm}$ tissue culture dishes coated with a thin film of rat-tail collagen polymerized by am- monia vapors (Ehrmann and Gey, 1956). In the experiments reported here, the neural tubes were retained in the cultures. NGF was not added to the the growth medium except where specifically indicated.

Immunocytochemistry and histochemistry. Indirect immunoffuorescence was used to visualize SLI-positive cells, as described previously (Maxwell et al., 1984a). Cells that were TH+ were also visualized by indirect immunofluorescence using the same protocol as for SLI, except that the fixation time was reduced to $40 \mathrm{~min}$. Antiserum directed against TH was the generous gift of Dr. A. W. Tank and was used at a final dilution of $1: 100$.

Histochemistry to reveal CA + cells was performed using the method of Furness et al. (1977), which results in a water-stable fluorophore. Cultures were washed once with Hanks' balanced salt solution (HBSS)HEPES, followed by incubation in $4 \%$ paraformaldehyde and $0.1 \%$ glutaraldehyde for $2 \mathrm{hr}$ at room temperature. Cultures were then washed in PBS and mounted using glycerol: PBS $(3: 1, \mathrm{vol} / \mathrm{vol})$. For neurofilament staining in conjunction with $\mathrm{CA}+$ cell visualization, the cultures were processed to reveal $\mathrm{CA}$ as described above, followed by indirect immunofluoresecnec for ncurofilaments, as described by Bennett et al. (1984). This allowed CA + cells to be observed using catecholamine optics and neurofilament staining using tetramethylrhodamine (TRITC) optics. Control experiments demonstrated that there is no overlap between CA and TRITC optics. Antisera raised in rabbits directed against the $70 \mathrm{kDa}$ (NF70) and $160 \mathrm{kDa}$ (NF160) chicken neurofilament proteins were generously provided by Dr. G. Bennett and were used at dilutions of $1: 150$ and 1:500, respectively. These antisera have been shown to be specific for the neurofilament protein they were raised against, and showed no cross-reactivity with each other (Bennett et al., 1984).

For visualization of TH-positive and neurofilament-positive structures in the same experiment, double-label indirect immunofluorescence was used. Monoclonal antibody to TH was the gift of Dr. H. Hatanaka and was used at a dilution of $1: 200$. The neurofilament antisera were those noted above. Cultures were either fixed in acetone at $-20^{\circ} \mathrm{C}$ for $10 \mathrm{~min}$ or in $4 \%$ paraformaldehyde for $40 \mathrm{~min}$. Both fixation protocols gave the same results. Cultures were grown on collagen-coated glass coverslips when acetone was used. Control experiments using the "incorrect" primary antibodies were performed to demonstrate that the fluorochrome-conjugated secondary antibodies possessed the required specificities. At the conclusion of the antibody staining, the cultures were mounted in a solution containing 1,4-diazobicyclo[2,2,2]octane to inhibit bleaching of the fluorescence (Johnson et al., 1982).

Uptake experiments. Growth medium was removed from the cells and the cultures were preincubated for $10 \mathrm{~min}$ in $0.65 \mathrm{ml}$ of medium containing Dulbecco's modified Eagle's medium with $4.5 \mathrm{gm} / \mathrm{liter}$ glucose without serum or chick embryo extract but with $1 \mathrm{~mm}$ ascorbate, $0.1 \mathrm{~mm}$ pargyline, and test drug where indicated. Cultures were then incubated for $30 \mathrm{~min}$ at $36.5^{\circ} \mathrm{C}$ in $5 \% \mathrm{CO}_{2}$ in the same medium containing $0.5 \mu \mathrm{M}{ }^{3} \mathrm{H}$-norepinephrine (NE). At the conclusion of the incubation, the cells were washed 5 times in HBSS-HEPES containing 1 mM nonradioactive NE, scraped from the dish into $100 \mu 1$ HBSS-HEPES and solubilized with $0.5 \mathrm{ml}$ Protosol (New England Nuclear). Samples were then treated with $100 \mu \mathrm{l}$ of $\mathrm{H}_{2} \mathrm{O}_{2}$ at $60^{\circ} \mathrm{C}$ for $30 \mathrm{~min}$ to bleach out any pigmentation resulting from melanocytes present in the sample. The radioactivity in the sample was measured in a liquid-scintillation spectrometer using Econofluor cocktail (New England Nuclear).

6-Hydroxydopamine treatment. For treatment with 6-hydroxydopamine, a $100 \times$ stock solution of $8 \mathrm{mg} / \mathrm{ml}$ was prepared fresh in HBSSHEPES. At the time of treatment, fresh ascorbate at $20 \mu \mathrm{g} / \mathrm{ml}$ was also added to the culture to retard oxidation of the 6-hydroxydopamine.

Reserpine treatment. Reserpine was prepared as a $1000 \times$ stock solution of $0.1 \mathrm{M}$ in dimethyl sulfoxide. Control cultures received an equal volume of dimethyl sulfoxide without reserpine.

Electron microscopy. Preparation of cultured cells for electron microscopy was carried out with the cells in situ in the culture dish. Cultures of the appropriate age were rinsed with warm HBSS-HEPES and incubated in the dark for $2 \mathrm{hr}$ at room temperature in a fixative consisting of $4 \%$ paraformaldehyde, $1 \%$ glutaraldehyde, $4 \%$ polyvinylpyrolidone, and $0.15 \%$ calcium chloride in $0.1 \mathrm{M}$ cacodylate buffer, $\mathrm{pH} 7.4$ (Grillo et al., 1974). Following fixation, the cultures were rinsed 3 times with $0.1 \mathrm{M}$ cacodylate buffer and observed under phase and fluorescent optics to locate CA + cells. Areas of the cultures containing CA + cells were circumscribed by scoring the culture dish with a sharp probe. Cultures were then postfixed in $1.0 \%$ osmium tetroxide in $0.1 \mathrm{M}$ cacodylate buffer for $30 \mathrm{~min}$ at room temperature, rinsed 3 times with cacodylate buffer, followed by 5 rinses in ice-cold $0.1 \mathrm{M}$ sodium acetate buffer, $\mathrm{pH} 5.0$. 


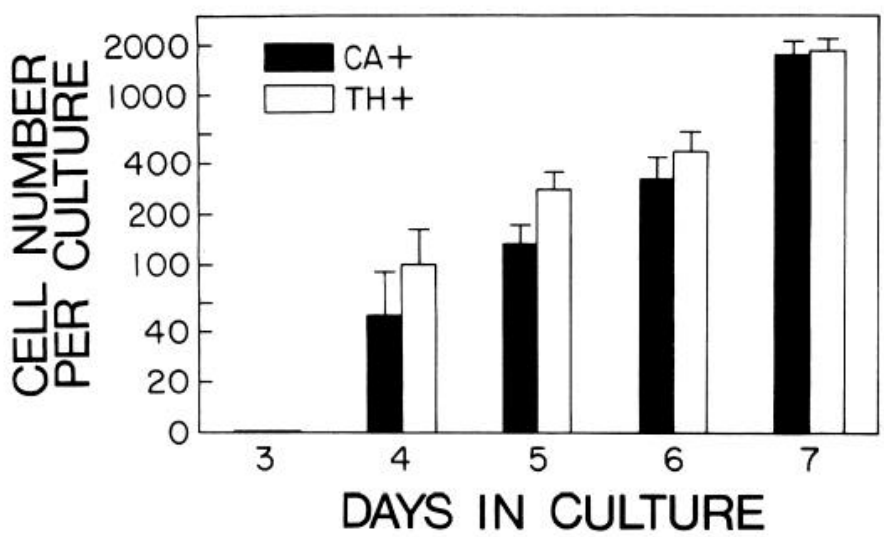

Figure 1. Developmental appearance of $\mathrm{TH}+$ and $\mathrm{CA}+$ cells in neural crest cultures. Cultures were grown as described in Materials and Methods and sister cultures were processed to reveal either $\mathrm{TH}+$ or $\mathrm{CA}+$ cells on the days indicated. The number of cells/culture positive for each trait was scored. Values are presented as the means \pm SEM. Note that the ordinate is plotted on a log scale.

The cultures were then stained en bloc using 1.0\% uranyl acetate in 0.05 M sodium acetate, $\mathrm{pH} 5.0$, for $2 \mathrm{hr}$ in the dark at $4^{\circ} \mathrm{C}$. Cultures were then rinsed 3 times in sodium acetate buffer, dehydrated in a graded series of ethanols, and embedded in Polybed 812 resin (Polysciences). They were then cured at $60^{\circ} \mathrm{C}$ for $24 \mathrm{hr}$. Marked areas of the embedded cultures were cut out with a jeweler's saw, mounted on epoxy stubs using cyanoacrylate cement, and trimmed to the appropriate size for thin-sectioning.

Sections $80-90 \mathrm{~nm}$ thick were cut on a Sorvall Porter-Blum MT-2B ultramicrotome and collected on 150-200-mesh copper grids. Most cultures were sectioned in a plane parallel to the bottom of the dish, starting in a plane above the cells so as not to miss any cells of interest. Thin sections were collected at $1 \mu \mathrm{m}$ intervals, beginning as soon as cells were encountered in the block, until the substrate was reached. Some cultures were sectioned perpendicular to the bottom of the dish. Sections were grid-stained in $5 \%$ uranyl acetate at $36^{\circ} \mathrm{C}$ for $30 \mathrm{~min}$ and then by $0.8 \%$ lead citrate at room temperature for $5 \mathrm{~min}$.

Sections were analyzed on a Phillips 300 electron microscope. Random nonduplicated fields with GV-containing cells were photographed by systematically scanning a single thin section and photographing each field encountered until 14 exposures were completed or all the fields with $\mathrm{GV}$ had been photographed. Only a single thin section from a given field containing CA + cells was analyzed for morphometry, thus eliminating the possibility that any GV were sampled more than once. Micrographs used for determinations of GV diameters were photographed at 50,000 $\times$ magnification and subsequently printed at a final magnification of $125,000 \times$. Micrographs used for vesicle-frequency determinations were photographed at $4000 \times$ magnification and printed at $12,000 \times$. A calibration grid was photographed with each sample in order to record the exact magnification, and the microscope objective lens current was reduced to 0 before each micrograph was taken to reduce the effects of hysteresis.

For morphometry, the outines of GV, cells, or nuclear profiles were digitized on a digitizing tablet (Numonics) interfaced to an LSI-11 computer (Digital Equipment Corporation). Using perimeter points, the area and mean diameter of the profiles were calculated as described in detail by Oliver (1985). Briefly, the longest axis of a given profile was defined as the longest line that divided the area into 2 equal areas. The average diameter was the average of twice the radial distance from the long axis to each perimeter point. At $125,000 \times$ magnification, the lower limit of resolution of vesicle-diameter measurements using this instrumentation was $4 \mathrm{~nm}$. Since the observed GV diameters differed from the true mean diameters because of the sectioning of some GV through planes other than the equator, the corrected mean GV diameter was calculated using the method of Giger and Riedwyl, as described by Weibel (1979).

Vesicle frequency was calculated by counting the number of GV in a given cell profile and then dividing that number by the area of cytoplasm, as expressed in a square microns. In cases where a nuclear profile was present in a cell profile, the nuclear area was subtracted from the total cellular area to yield the cytoplasmic area.

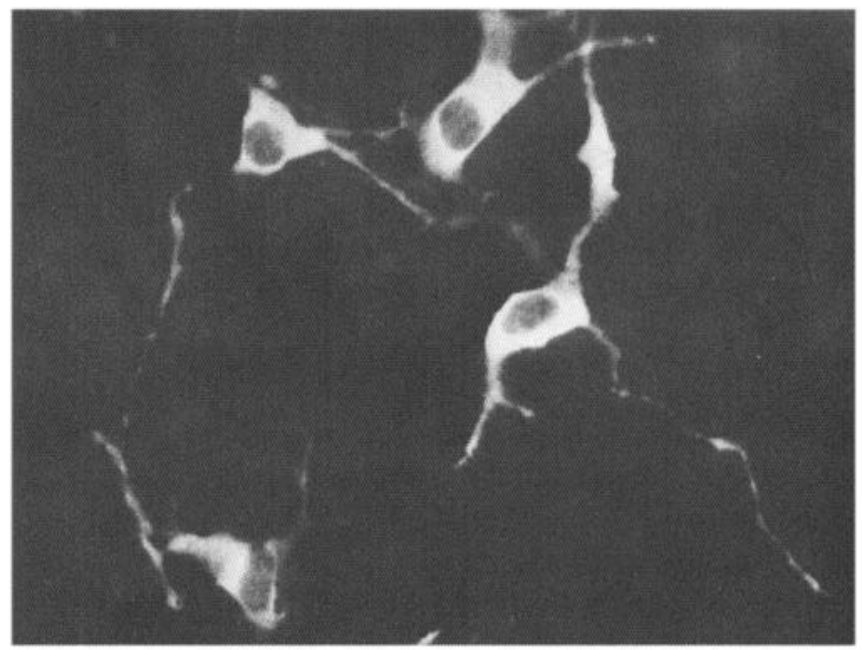

Figure 2. Morphology of TH + cells that develop in neural crest cultures. The photograph shows $\mathrm{TH}+$ cells in a neural crest culture after $7 \mathrm{~d}$ in vitro, visualized using using antiserum to TH and indirect immunofluorescence, as described in Materials and Methods. Immunoreactivity to TH is observed in cell bodies and in cellular processes. The morphology of the $\mathrm{TH}+$ cells is very similar to that previously reported for $\mathrm{CA}+$ cells. Magnification, $\times 592$.

\section{Results}

Immunocytochemistry and pharmacology of $\mathrm{CA}+$ cells

Previous studies have documented some of the features of the histochemically and biochemically detectable $\mathrm{CA}+$ cells that differentiate in neural crest organ and cell cultures (Cohen, 1972, 1977; Norr, 1973; Kahn et al., 1980; Sieber-Blum and Cohen, 1980; Fauquet et al., 1981; Maxwell et al., 1982; Kahn and Sieber-Blum, 1983; Maxwell and Sietz, 1983, 1985; Howard and Bronner-Fraser, 1986). We wished to examine several aspects of the adrenergic phenotype of these $\mathrm{CA}+$ cells in more detail. As one part of this analysis, we have compared the pattern of appearance of $\mathrm{TH}+$ and $\mathrm{CA}+$ cells in these cultures. In particular, we wished to determine whether $\mathrm{TH}+$ cells appeared prior to cells with endogenous CA stores. We also wished to determine whether significant numbers of cells were $\mathrm{TH}+$, but did not contain detectable CA. As shown in Figure 1, neither $\mathrm{TH}+$ nor $\mathrm{CA}+$ cells were observed prior to $4 \mathrm{~d}$ in vitro under the cell culture conditions used. By $4 \mathrm{~d}$ in vitro, small numbers of both cell types were seen. The number of both cell types increased rapidly between 4 and $7 \mathrm{~d}$ in vitro. Similar numbers of $\mathrm{TH}+$ and $\mathrm{CA}+$ cells were observed at any given time point. In addition, the morphology of the $\mathrm{TH}+$ cells in the cultures was very similar to that observed for $\mathrm{CA}+$ cells (Fig. 2). The $\mathrm{TH}+$ cells were often located in the region of the neural crest outgrowth adjacent to the neural tube, as was the case for $\mathrm{CA}+$ cells.

One diagnostic feature of neurons is the presence of neurofilaments in their cell bodies and processes (Weber et al., 1983). Neural crest primary cultures after $7 \mathrm{~d}$ in vitro were processed to visualize $\mathrm{CA}+$ cells and then stained with antisera specific for either the NF70 or the NF160 subunits of chicken neurofilament protein. We found that neither the processes nor the cell bodies of CA + cells were stained using either neurofilament antiserum (Fig. 3).

Neurofilament-immunoreactive processes were present in the 

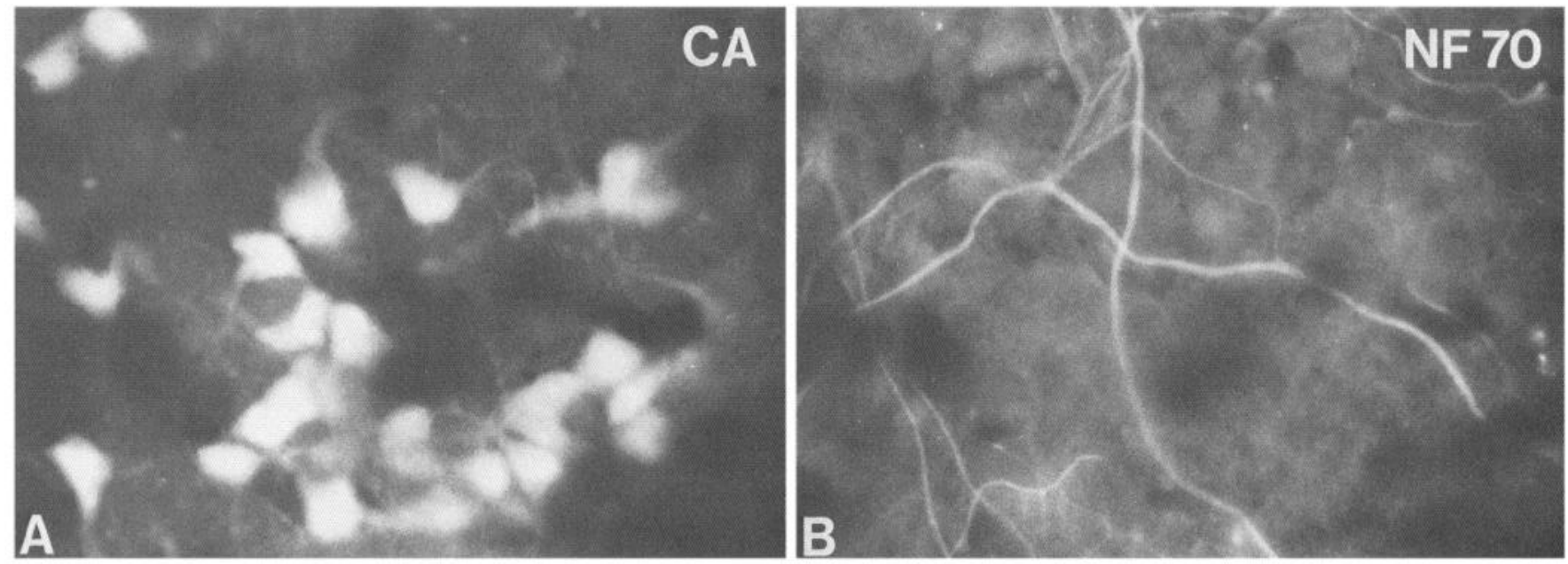

Figure 3. The CA+ cells that develop in neural crest cultures do not exhibit immunoreactivity to the NF70 neurofilament protein. Neural crest cultures were grown for $7 \mathrm{~d}$ in vitro and then processed in double-label experiments to reveal CA+ and NF70. $A$, CA+ cells. $B$, The same field as in $A$ viewed to reveal NF70 + structures. NF70 is present in cellular processes that originate in cells of the neural tube, but is absent from the CA+ cells. Magnification, $\times 520$.

cultures and were observed to originate mainly from cell bodies present in the neural tube. To control for the possibility that the histochemical procedure used to visualize CA+ cells may have reduced the ability of neurofilament proteins to be recognized by the antibody, we compared neural crest cultures stained for neurofilament using a standard immunocytochemical protocol, which employed $4 \%$ paraformaldehyde fixation, to cultures stained after visualization of $\mathrm{CA}+$ cells. The pattern of neurofilament staining was similar in both conditions. There was, however, some reduction in the intensity of the neurofilament staining when $\mathrm{CA}+$ cells were also visualized.

As an alternative approach, we performed double-label immunocytochemical experiments using monoclononal antibodies directed against $\mathrm{TH}$ produced in a mouse and the antisera directed against the NF70 or NF160 chicken neurofilament proteins raised in rabbits. As illustrated in Figure 4, these experiments demonstrated that the $\mathrm{TH}+$ cells did not contain immunocytochemically detectable NF70 or NF160. The absence of NF70 and NF160 in TH+ cells at $7 \mathrm{~d}$ in vitro could have been phenomenon of developmental maturation. For this reason, cultures were also studied after longer times in vitro. In TH NF160 double-label experiments performed on cultures after $11 \mathrm{~d}$ in vitro, only $1 \mathrm{TH}+$ cell of 578 was $\mathrm{NF} 160+$, while at $18 \mathrm{~d}$ in vitro only $2 \mathrm{TH}+$ cells of 379 were observed to be NF160+. In TH NF70 double-label experiments performed after 19 and $26 \mathrm{~d}$ in vitro, none of $267 \mathrm{TH}+$ cells scored was NF70+.

There was, however, abundant intense immunoreactivity to these neurofilament proteins present in other cells in the cultures, sometimes located in the same microscopic fields as the $\mathrm{TH}+$ cells (Fig. 4, $B, D$ ). This immunoreactivity was present in numerous processes whose cell bodies were located in the neural tube, which had been intentionally retained in these cultures.

In addition to the $\mathrm{NF} 70+$ and $\mathrm{NF} 160+$ processes present in some $\mathrm{TH}-$ cells, there were also some NF160+ and NF70+ cell bodies that were $\mathrm{TH}-$ present in the neural crest outgrowth regions of the culture (Fig. 5). The morphology of some of these $\mathrm{NF}+\mathrm{TH}-$ cells resembled that of neurons with an enlarged cell body and prominent processes, while other NF+ TH - cells had a somewhat less neuronal morphology. The presence of these $\mathrm{NF}+\mathrm{TH}-$ cells suggests that neuronal cells that are not adrenergic differentiate in these neural crest cultures in addition to the $\mathrm{TH}+$ cell population.

In other systems, neurons and neuroendocrine cells that metabolize CAs have been shown to possess specific uptake systems for these compounds (Iversen, 1967). In an effort to assess the uptake properties of the $\mathrm{CA}+$ cells that develop in neural crest cultures, we have examined the sensitivity of this process to conditions with known effects on CA uptake in other systems. As shown in Figure 6, the uptake and storage of ${ }^{3} \mathrm{H}-\mathrm{NE}$ was blocked in the presence of desmethylimipramine, an inhibitor of uptake I, and by incubation at $0^{\circ} \mathrm{C}$. In contrast, this uptake and storage were unaffected by normetanephrine, an inhibitor of uptake II.

Acute overnight application of the alkaloid reserpine, which depletes CA stores from vesicles, resulted in the absence of histochemically detectable CA + cells from all neural crest cultures $(n=6)$. Control experiments in which reserpine was added 10 min prior to CA histochemistry demonstrated that reserpine does not interfere with the histochemical reaction used to detect $\mathrm{CA}+$ cells. The effect of acute overnight treatment with reserpine was not reversible over a period of at least $7 \mathrm{~d}$. Chronic administration of reserpine from day 2 to 7 in vitro resulted in the absence of $\mathrm{CA}+$ cells in the cultures, but the presence of normal numbers of $\mathrm{TH}+$ and $\mathrm{SLI}+$ cells (Fig. 7). Since CA+ cells are not detectable until day 4 in vitro at the earliest, this suggests that $\mathrm{CA}$ content in vesicles is not required for the development of $\mathrm{TH}+$ and $\mathrm{SLI}+$ cells.

The compound 6-hydroxydopamine has profound effects on some adrenergic neuron populations in the peripheral nervous system (Thoenen and Tranzer, 1968; Tranzer and Thoenen, 1968). In adult animals it destroys adrenergic nerve endings, while in neonatal mammals the cell bodies are also destroyed (Angeletti and Levi-Montalcini, 1970; Finch et al., 1973). When 6-hydroxydopamine was administered to neural crest cultures that contained CA+ cells on days 7 and 9 in vitro, and was then processed to reveal CA + cells on day 11 in vitro, $1927 \pm 522$ (mean $\pm \mathrm{SEM} ; n=4) \mathrm{CA}+$ cells were present in the control condition and $1757 \pm 454(n=4)$ in the 6-hydroxydopamine- 

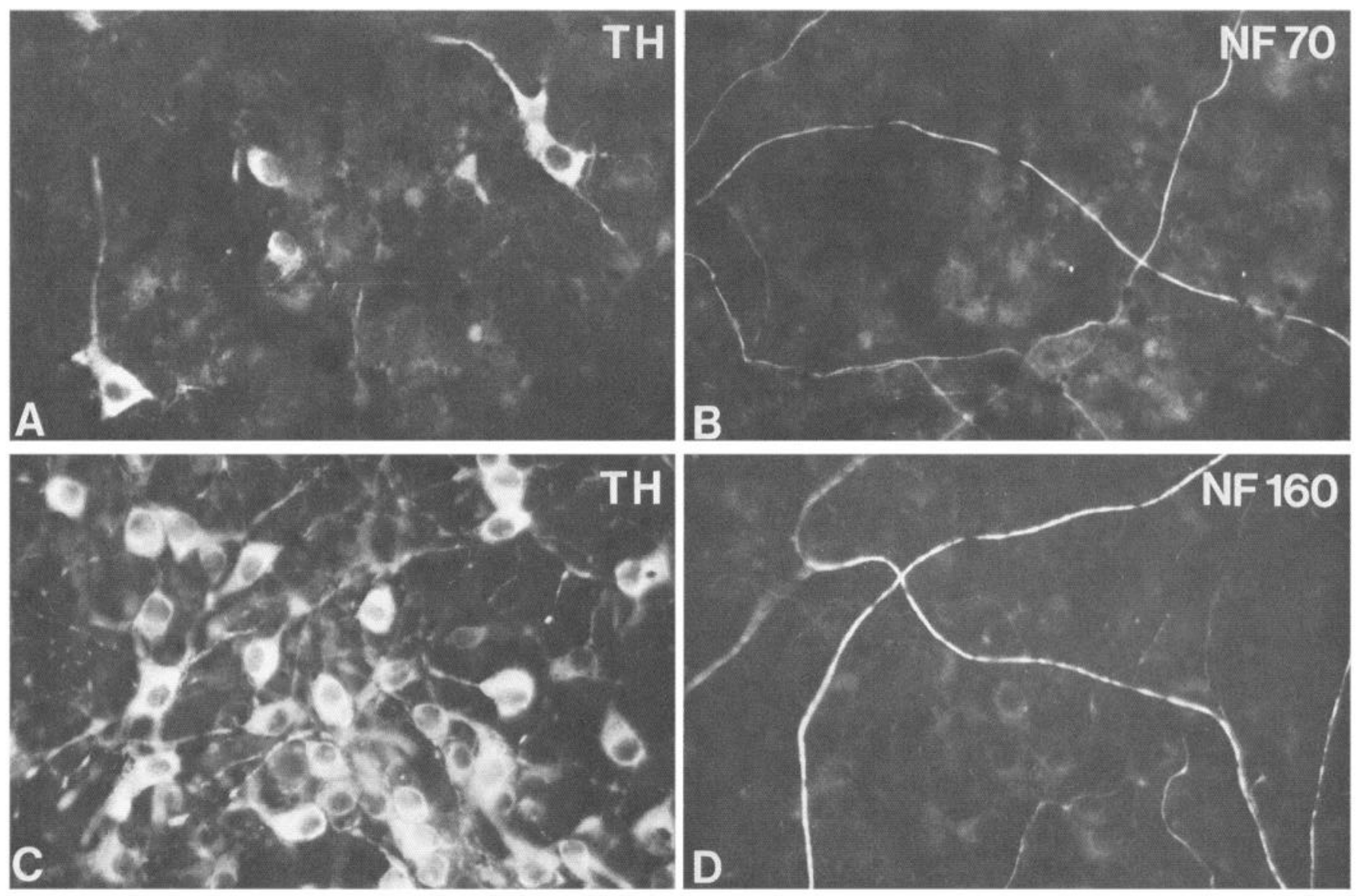

Figure 4. Neurofilament proteins NF70 and NF160 are not detectable in TH+ cells that differentiate in neural crest cultures. Neural crest cultures were grown for $7 \mathrm{~d}$ in vitro and then processed in double-label indirect immunofluorescence experiments, as described in Materials and Methods, to reveal $\mathrm{TH}+$ cells and NF70+ structures or TH+ cells and NF160+ structures. $A, \mathrm{TH}+$ cells. $B, \mathrm{NF} 70+$ structures in the same field as in $A$. $C, \mathrm{TH}+$ cells. $D, \mathrm{NF} 160+$ structures in the same field as in $C$. In both the NF70 and NF160 cases, neurofilament-positive fibers whose cell bodies of origin are in the neural tube are present, but no neurofilament immunoreactivity is observed in the TH+ cells. In $D$, the faint fluorescence seen in the region of the $\mathrm{TH}+$ cells is equivalent to the background observed when $\mathrm{TH}+$ cells are stained using the appropriate TRITC-labeled second antibodies and viewed using FITC optics. Magnification, $\times 520$.

treated cultures. The light-microscopic appearance of the cells was the same in both conditions. Cultures that were allowed to grow for up to $7 \mathrm{~d}$ after 6-hydroxydopamine treatment also showed no effect on $\mathrm{CA}+$ cell survival or light-microscopic morphology. In contrast to this lack of effect on neural crest cells, the same regimen of 6-hydroxydopamine was effective in the elimination of brightly fluorescent $\mathrm{CA}+$ cells from embryonic day 11 quail sympathetic ganglia grown in tissue culture.

NGF is a compound with well-documented effects on several populations of neural crest-derived cells (Levi-Montalcini and Angeletti, 1968; Greene and Shooter, 1980; Thoenen and Barde, 1980). Under growth conditions in which chick embryo extract was present in the medium, the addition of exogenous NGF did not affect the number of histochemically detectable CA+ cells that developed. When cells were grown from day 2 to 7 in vitro in $0,10,50$, and $100 \mathrm{ng} / \mathrm{ml}$ of NGF, there were $2528 \pm 409$, $2186 \pm 413,2107 \pm 622$, and $2327 \pm 566 \mathrm{CA}+$ cells present per culture, respectively, on day 7 in vitro (mean \pm SEM; $n=$ 5 in all cases). In addition, the morphology of the CA+ cells was similar in the presence and absence of exogenous NGF. Analysis of our growth medium with embryo extract determined that there was less than $2 \mathrm{ng} / \mathrm{ml}$ NGF-like immunoreactive material, as determined by a modified, one-site radioimmu- noassay (RIA) for NGF using antiserum to mouse NGF (M. Rosenberg, personal communication). While chick embryo extract does not contain molecules that are immunologically similar to mouse NGF, there may be other molecules present that may have NGF activity (Cohen and Konigsberg, 1975; Gotz et al., 1986; Shelton et al., 1986) and whose presence may prevent detection of a response to exogenously added NGF. To try to rule out this possibility, a second series of experiments was performed. In this set of experiments, the cultures were grown in medium with chick embryo extract, but no NGF, for $7 \mathrm{~d}$ in order to generate $\mathrm{CA}+$ cells, and then shifted into medium without chick embryo extract, but containing $15 \%$ horse serum (which does not possess NGF activity), with or without exogenous NGF, at $100 \mathrm{ng} / \mathrm{ml}$. Six days after the medium shift, the cultures were processed to reveal CA + cells. The results of these experiments showed that $1216 \pm 383$ (mean \pm SEM; $n=4)$ CA cells per culture were present without exogenous NGF, while $1025 \pm 361(n=4)$ cells were present when exogenous NGF was added. The morphology of the CA + cells was the same in both cases, with brightly fluorescent cell bodies and some processes present. Thus, even in the absence of chick embryo extract, NGF did not alter the number of $\mathrm{CA}+$ cells or their morphology. 

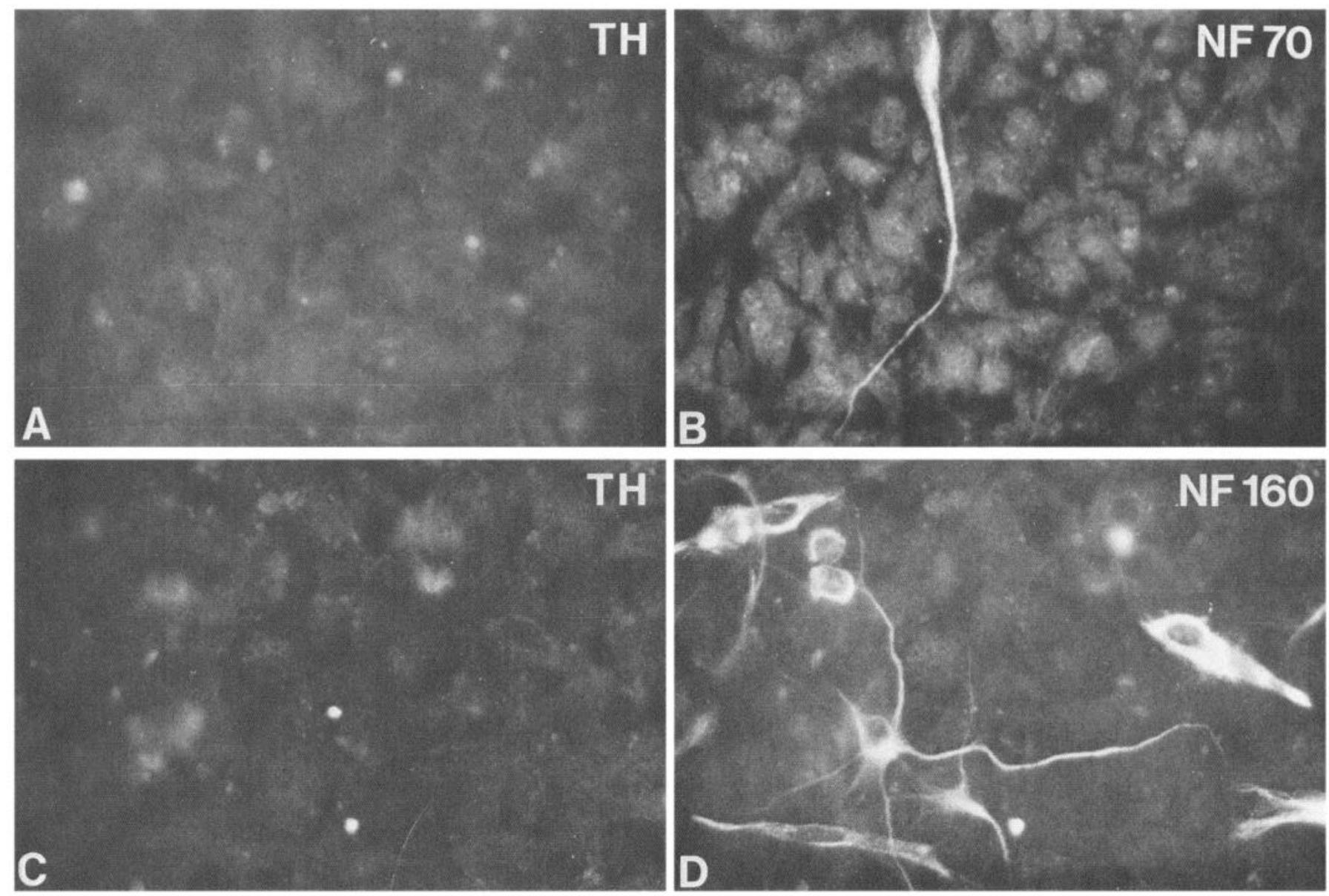

Figure 5. Cells that are NF70+ and NF160+ but TH- are present in the neural crest outgrowths. Neural crest cultures were grown for $7 \mathrm{~d}$ in vitro and then processed for double-label indirect immunofluorescence to detect TH and NF70 or NF160. $A$, TH. B, NF70+ cell in the same field as in $A$. $C$, TH. $D$, The same field as in $C$, viewed to reveal NF160+ structures. Magnification, $\times 520$.

\section{Ultrastructural properties of $\mathrm{CA}+$ cells}

While the light-microscopic data on the properties of CA + cells in neural crest cultures are informative in many respects, there are certain properties that can only be analyzed at the ultrastructural level. In particular, this is the case for information concerning the vesicular content of the $\mathrm{CA}+$ cells, which is one important diagnostic feature for the type of $\mathrm{CA}+$ cell present. Accordingly, we have performed a correlative light- and electron-microscopic study of the ultrastructure of CA+ cells in neural crest cultures at several stages of development.

The CA + cells were a small subpopulation of the cells in our neural crest cultures, and it was difficult to predict precisely where in a culture the CA+ cells were present. This precluded a random blind sampling of the cultures for any meaningful ultrastructural analysis of CA + cells. To overcome this difficulty, we have used the method of Grillo et al. (1974), which allowed the identification of CA + cells in the light microscope and subsequent analysis of the same cells in the electron microscope. Using this procedure, we were able to identify CA+ cells that were comparable in number, morphology, and spatial distribution in the cultures to those observed using the method of Furness et al. (1977).

When we examined areas of the cultures that contained CA+ cells with the electron microscope, we observed, in addition to melanocytes, large numbers of unpigmented cells. Many of these unpigmented cells contained in their cytoplasms membranebound vesicles with electron-dense cores, characteristic of CAstorage vesicles observed in other systems (Figs. 8, 9). Our examination of thin sections collected at intervals from the top to the bottom of the cultures showed that the GV-containing cells were consistently found in the lower layers of the cultures adjacent to the collagen substrate, where they were often beneath pigmented or nonpigmented cells. Our analysis determined that the GV-containing cells corresponded to $\mathrm{CA}+$ cells seen in the light microscope. We established that there was a one-to-one correspondence between the number and spatial arrangement of $\mathrm{CA}+$ and GV-containing cells (Fig. 10). Analysis of microscopic fields without $\mathrm{CA}+$ cells revealed no GV-containing cells.

The GV-containing cells were generally small, with cell bodies $10-20 \mu \mathrm{m}$ along their longest axis. The nuclei were irregular in shape and euchromatic. In many cases a prominent nucleolus was present, in addition to characteristic small amounts of heterochromatin found in quail nuclei located adjacent to the nuclear membrane. The cytoplasm contained numerous mitochondria and Golgi profiles, a few areas of rough endoplasmic reticulum, and abundant polyribosomes (Fig. 11). On average, the cytoplasmic ground substance of the GV-containing cells was darker than that of unpigmented cells that did not contain GV (Fig. 8). The principal distinguishing feature of these cells, 


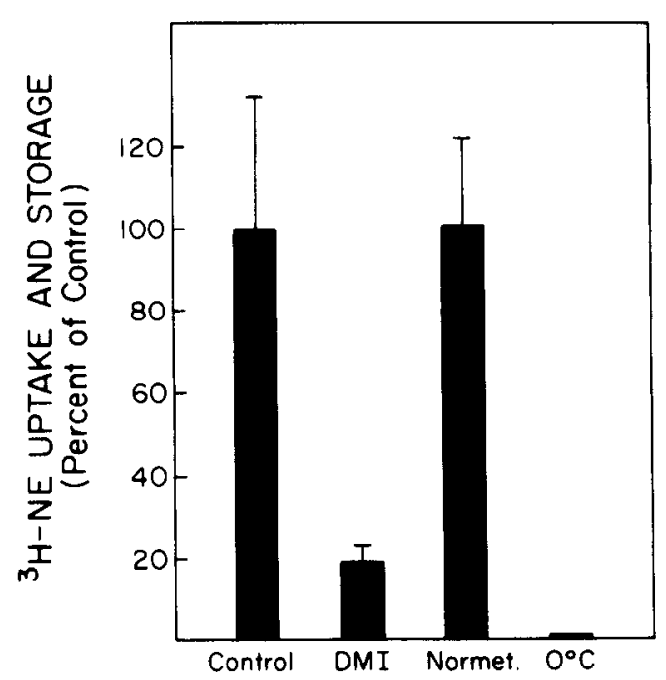

Figure 6. Catecholamine uptake and storage properties of neural crest cultures. Neural crest cultures after $7 \mathrm{~d}$ in vitro were incubated with 0.5 $\mu \mathrm{M}{ }^{3} \mathrm{H}-\mathrm{NE}$ for $30 \mathrm{~min}$ and then processed as described in Materials and Methods. The amount of cell-associated radioactivity, accumulated under control conditions, in the presence of $2 \mu \mathrm{M}$ desmethylimipramine $(D M I), 10 \mu \mathrm{M}$ normetanephrine (Normet), or incubation at $0^{\circ} \mathrm{C}$, is shown. Values are expressed as a percentage of the mean control value, which was normalized to $100 \%$. Error bars show \pm SEM with 5-7 determinations per condition.

however, was the presence of numerous GV. These were round or oval, bounded by a typical unit membrane, and possessed an electron-dense core with an electron-lucent halo. Typically the electron-dense cores were located eccentrically in the GV.

Qualitatively, the GV-containing cells were morphologically similar at all ages examined, as described above. Cells with $G V$ in their cytoplasm were detected as early as $4 \mathrm{~d}$ in vitro, but the number of such cells was very small. Since the presence of the GV was the most striking fcature of the CA + cells, we performed a morphometric analysis on the $\mathrm{GV}$ present in cultures after 5 , 7,14 , and $21 \mathrm{~d}$ in vitro in order to determine quantitatively the characteristics of these cells and the changes that occurred in culture. As shown in Figure 12, the observed vesicle diameters ranged from 50 to $600 \mathrm{~nm}$, with a major fraction of vesicle diameters clustered $\pm 50 \mathrm{~nm}$ around a modal value in the range of 85-1 $15 \mathrm{~nm}$ for the ages examined. There was no evidence of a dramatic change in the pattern of vesicle diameters over the period from day 5 to 21 in vitro (Fig. 12, Table 1), although the population of GV greater than $200 \mathrm{~nm}$ in diameter was somewhat greater at $21 \mathrm{~d}$ in vitro. The frequency of GV (number of $\mathrm{GV} / \mu \mathrm{m}^{2}$ of cytoplasm) also remained quite constant over the period of 5-21 d in vitro. At 5, 7, 14, and $21 \mathrm{~d}$ in vitro, there were $2.55 \pm 2.60$ (mean $\pm \mathrm{SD})(n=39), 3.19 \pm 2.66(n=89)$, $2.29 \pm 1.69(n=77)$, and $2.06 \pm 0.89(n=41) \mathrm{GV} / \mu \mathrm{m}^{2}$ of cytoplasm, respectively. The $n$ in this case refers to the number of cell profiles examined. On average, the GV occupied approximately $5 \%$ of the total cytoplasmic area of the cell.

Fluorescent processes were seen extending from many $\mathrm{CA}+$ cells and were often observed to run among clusters of GVcontaining cells. Ihese processes were characterized by a pale cytoplasm lacking ribosomes, but containing numerous microtubules arraycd longitudinally with dense core GV often lined up along the microtubules (Fig. 13).

In cultures after 5 and $7 \mathrm{~d}$ in vitro, synaptic profiles were not observed. However, in cultures after 14 and $21 \mathrm{~d}$ in vitro, nerve

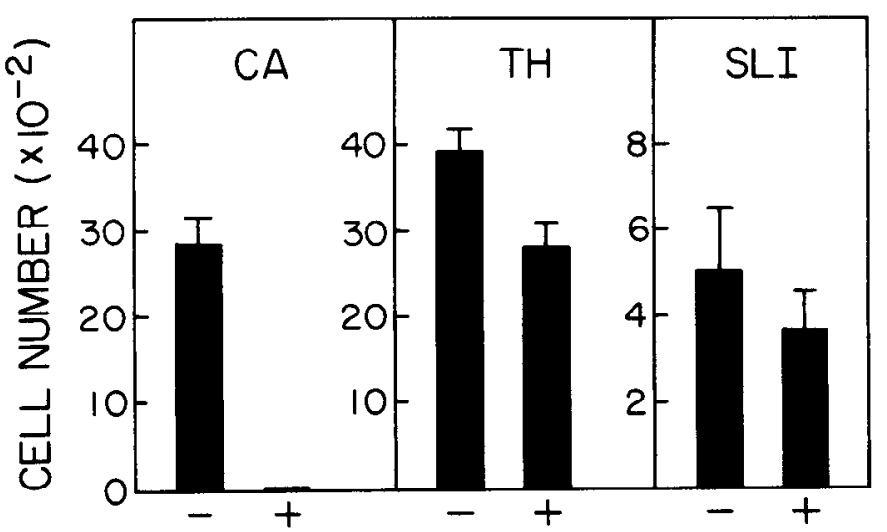

Figure 7. The effect of chronic reserpine treatment on the appearance of CA,$+ \mathrm{TH}+$, and SLI+ cells. Neural crest cultures were grown with either $10 \mu \mathrm{M}$ reserpine $(+)$ or dimethyl sulfoxide (the reserpine solvent, -) for days 2-7 in vitro, and then analyzed on day 7 for the number of $\mathrm{CA}+, \mathrm{TH}+$, or SLI+ cells, as described in Materials and Methods. Values are expressed as the mean \pm SEM with 5-7 determinations for each condition.

terminals were frequently seen adjacent to GV-containing cell bodies. In some terminal profiles, synaptic membrane specializations were evident (Fig. 14). One typical terminal contained predominantly clear vesicles, $59 \pm 10 \mathrm{~nm}$ in diameter (mean \pm $\mathrm{SD} ; n=37$ vesicles), with a few dense core vesicles $104 \pm 26$ $\mathrm{nm}$ in diameter (mean $\pm \mathrm{SD} ; n=25$ vesicles). The cell bodies of origin of these terminals are not known.

\section{Discussion}

In the present paper we have examined several properties of the $\mathrm{CA}+$ cells that differentiate in neural crest cultures in order to assess the nature and extent of their development. These experiments, together with other available information, have allowed us to conclude that the $\mathrm{CA}+$ cells that develop in our neural crest cultures resemble SIF cells in many respects. This phenotype is consistent with these $\mathrm{CA}+$ cells being either a SIF-like developmental intermediate that is stabilized by our culture conditions or a terminally differentiated SIF-like cell type such as those found in some adult sympathetic ganglia and extra-adrenal chromaffin tissue.

\section{Correspondence of $\mathrm{TH}+$ and $\mathrm{CA}+$ cells}

The CA+ cells in these neural crest cultures develop from a $\mathrm{CA}-$ cell population that is also $\mathrm{TH}-$. The temporal appearances of $\mathrm{TH}+$ and $\mathrm{CA}+$ cells are very similar, suggesting that, at least with a time resolution of days, there is no appreciable lag between the appearance of $\mathrm{TH}$ and the capabiity to synthesize and store CA. These findings are in agreement with previous biochemical observations comparing the time courses of appearance of dopamine- $\beta$-hydroxylase enzyme activity and the production and storage of radiolabeled CA from radioactive tyrosine by intact cells (Kahn et al., 1980; Maxwell et al., 1982). The present results, comparing the number of $\mathrm{TH}+$ and $\mathrm{CA}+$ cells as a function of time in culture, also demonstrate that, after $7 \mathrm{~d}$ in vitro, the number of cells with both markers in their cell bodies is similar. This suggests that there is no large population of cells that is $\mathrm{TH}+$ but $\mathrm{CA}-$ in the cell body. In addition, there does not appear to be a large population of $\mathrm{CA}+$ processes present without $\mathrm{CA}+$ cell bodies. This phenotype might be expected if large numbers of cells resembling principal sym- 


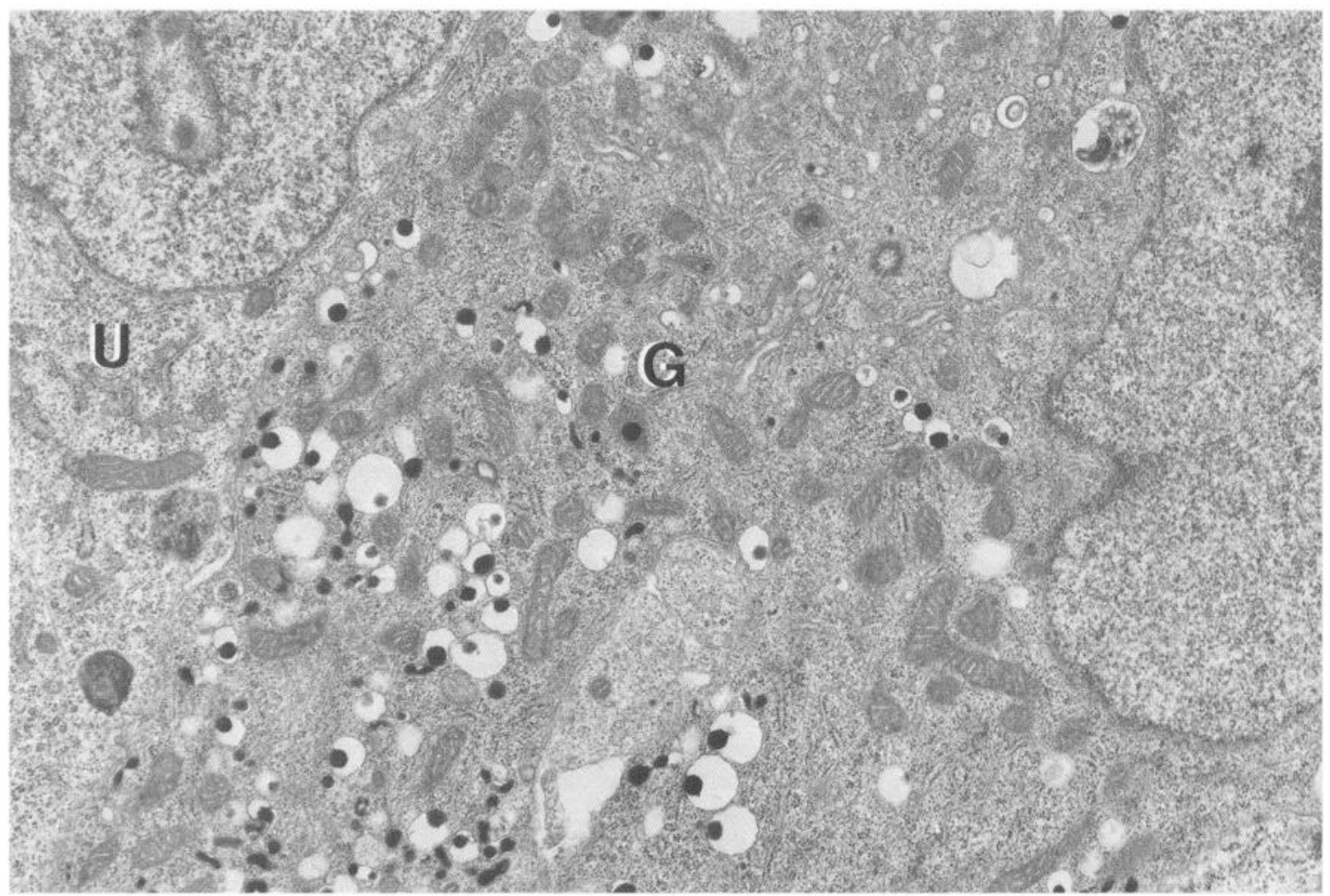

Figure 8. Ultrastructure of CA + cell cytoplasm at $5 \mathrm{~d}$ in vitro. Electron micrograph showing portions of 2 cells from a neural crest primary culture after $5 \mathrm{~d}$ in vitro. The cell labeled $G$ contains numerous GV ranging from 50 to $600 \mathrm{~nm}$ (see Fig. 12). These GV contain eccentrically located dense cores. Also present in the cytoplasm are numerous mitochondria and free ribosomes. The cytoplasm of the cells with GV is darker than that of the adjacent unpigmented cell $(U)$, which lacks GV. Magnification, $\times 14,560$.

pathetic neurons were present in these cultures (Doupe et al., $1985 \mathrm{a}, \mathrm{b})$.

\section{Neurofilament immunoreactivity}

One very characteristic feature of neuronal differentiation is the expression of neurofilament proteins. The expression of neurofilament proteins is a relatively early event in the differentiation of many neuron populations, including some autonomic neurons (Tapscott et al., 1981; Jacobs et al., 1982; Ziller et al., 1983; Cochard and Paulin, 1984; Anderson and Axel, 1986). Our data indicate that virtually all the $\mathrm{CA}+$ and $\mathrm{TH}+$ cells that differentiate in our neural crest cultures lack detectable NF70 and NF160 in either their cell bodies or processes. This lack of neurofilament immunoreactivity appears to be a relatively stable trait of the $\mathrm{CA}+$ and $\mathrm{TH}+$ cells in these cultures, since in cultures kept as long as $26 \mathrm{~d}$ in vitro the $\mathrm{TH}+$ cells did not possess neurofilament immunoreactivity.

It has been reported that in $\mathrm{PC} 12$ cells grown in the absence of NGF, and in embryonic rat neuronal precursors, neurofilament immunoreactivity can be detected in a perinuclear "ball" (Lee and Page, 1984; Anderson and Axel, 1986). Also, immunoreactivity to NF160 has been observed in young avian neural crest cells in vivo that are likely the precursors of enteric neurons (Payette et al., 1984). We have not observed such neurofilament staining in our $\mathrm{CA}+$ and $\mathrm{TH}+$ cells in neural crest cultures, which suggests that our $\mathrm{CA}+$ and $\mathrm{TH}+$ cells are at a different stage of developmental maturation than these other cell types.

Many fibers and some cell bodies that do have NF70 and NF160 can be detected in other cells in these cultures. This neurofilament immunoreactivity in $\mathrm{CA}-$ and $\mathrm{TH}$ - cells serves as an internal control for the sensitivity and specificity of our immunocytochemical procedures. In addition, the presence of neurofilament-positive $\mathrm{TH}$ - cells in the neural crest outgrowths points to the differentiation of neuronal cell types in these trunk neural crest cultures that do not have adrenergic traits. These may include cells with some of the properties of sensory, parasympathetic, and enteric neurons, as well as nonadrenergic sympathetic neurons (Kahn et al., 1980; Fauquet et al., 1981; Maxwell et al., 1982; Ziller et al., 1983; Mackey et al., 1986; SieberBlum et al., 1986).

\section{CA uptake and storage properties}

Our data on the uptake and storage of ${ }^{3} \mathrm{H}-\mathrm{NE}$ are consistent with the view that some cells in our neural crest cultures acquire an uptake I-like system similar to that observed in other developing and mature adrenergic cell populations in vivo and in vitro (Iversen, 1967; Patterson et al., 1975; Greene and Rein, 1977; Rothman et al., 1978). Previous autoradiographic evidence and histochemistry for $\mathrm{CA}+$ cells, when correlated with data on the evoked release of ${ }^{3} \mathrm{H}-\mathrm{NE}$, strongly suggested that it is the subpopulation of histochemically detectable $\mathrm{CA}+$ cells that is responsible for the uptake and storage of ${ }^{3} \mathrm{H}-\mathrm{NE}$ (Maxwell and Sietz, 1983). This CA+ cell population is sensitive to reserpine administered in both acute and chronic regimens. It has been reported that some interneuron populations of older embryonic sympathetic ganglia are reserpine-resistant (Benitez et al., 1973, 1974). This does not appear to be the case for the $\mathrm{CA}+$ cells that develop in our cultures. While the chronic 


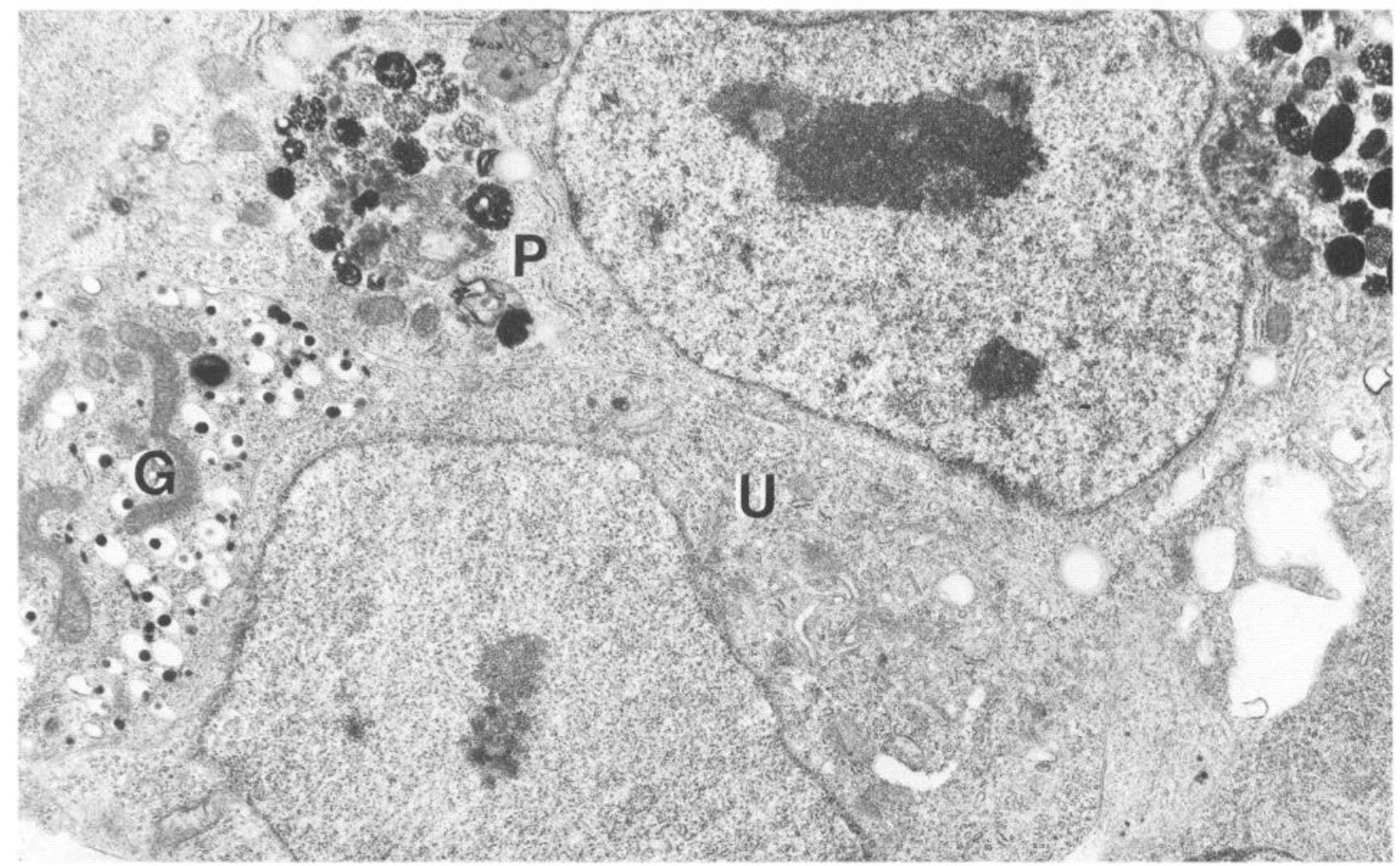

Figure 9. Comparison of the ultrastructure of $\mathrm{CA}+$, unpigmented and melanocyte cytoplasm at $5 \mathrm{~d}$ in vitro. Electron micrograph of portions of 3 cells from a neural crest cultures after $5 \mathrm{~d}$ in vitro. At the top is a pigmented cell $(P)$ containing melanosomes. At the left is a portion of a CA+ cell $(G)$ containing numerous GV. At the bottom is an unpigmented cell $(U)$ without GV. Magnification, $\times 12,207$.

administration of reserpine eliminates the appearance of $\mathrm{CA}+$ cells, TH+ and SLI+ cells are present in normal numbers. These data indicate that reserpine acts on these cells by depletion of $\mathrm{CA}$ stores and not by killing CA + cells. Furthermore, these data show that the presence of CA stores in vesicles is not necessary for the development of SLI. Since reserpine is present from day 2 to 7 in these experiments, and CA is not detectable until day 4 in control cultures, the SLI+ cells must arise in the absence of histochemically detectable CA. Since we assayed SLI cell number and not SLI content, we do not know if reserpine altered peptide content. Other studies have demonstrated varied effects of reserpine on peptide metabolism, which are probably dependent on the cell type and species examined (Wilson et al., 1980, 1981; Bohn et al., 1983; Kessler, 1985).

The CA + cells that develop in neural crest cultures do not exhibit a dramatic response to exogenous NGF with respect to either the number of cells that differentiates and survives or the light-microscopic morphology of the cells. This is in contrast to the very strong dependence on NGF for survival exhibited by older embryonic avian sympathetic and sensory neurons (Greene, $1977 \mathrm{a}, \mathrm{b})$. However, during the early stages of avian sympathetic and sensory ganglion development, neuronal survival and differentiation do not require the presence of NGF (Winick and Greenberg, 1965; Partlow and Larrabee, 1971; Barde et al., 1980; Edgar et al., 1981). Also, the SIF-like cells that develop in tissue cultures of older embryonic chick sympathetic ganglia do not require NGF for their survival and differentiation (Jacobowitz and Greene, 1974). Thus, the apparent lack of an NGF response by the $\mathrm{CA}+$ cells that differentiate in our neural crest cultures is consistent with either a SIF-like cell phenotype or an early stage of principal sympathetic neuron development.

Our data are consistent with recent reports that $\mathrm{CA}+$ and $\mathrm{TH}+$ cells in neural crest cultures grown in the absence of NGF do not possess a significant ability to bind NGF, suggesting that they lack NGF receptors (Bernd, 1986a; Greiner and Guroff, 1986). Thus, the most straightforward explanation for the lack of a response to NGF by CA+ cells is that they lack NGF receptors. It should be noted, however, that other cells in these neural crest cultures do possess NGF receptors (End et al., 1983; Bernd, 1985, 1986b; Greiner et al., 1985, 1986). Recent data by Bernd (1986a) suggest that when neural crest cultures are grown in the presence of NGF, some TH+ cells with NGF receptors are present. The number of these NGF-binding TH+ cells has not been reported. Unless the number is quite large, it is possible that they would not have been detected by us given the variability of total $\mathrm{CA}+$ cell number from culture to culture. In addition, we cannot exclude the possibility that $\mathrm{CA}+$ cells might exhibit an NGF response by an alteration of metabolism without affecting cell survival and hence cell number.

The CA + cells in neural crest cultures are resistant to the administration of doses of 6-hydroxydopamine that are effective in killing embryonic quail sympathetic neurons. This resistance to 6-hydroxydopamine treatment may be related to the relative insensitivity of these cultures to NGF. Aloe et al. (1975) have shown that NGF can protect rat sympathetic neurons against the effects of 6-hydroxydopamine with respect to cell survival. They suggested that perhaps cells that are insensitive to NGF may also be resistant to 6-hydroxydopamine (Levi-Montalcini and Aloe, 1980). While our CA+ cells in neural crest cultures are not killed by 6-hydroxydopamine, it is possible that the 


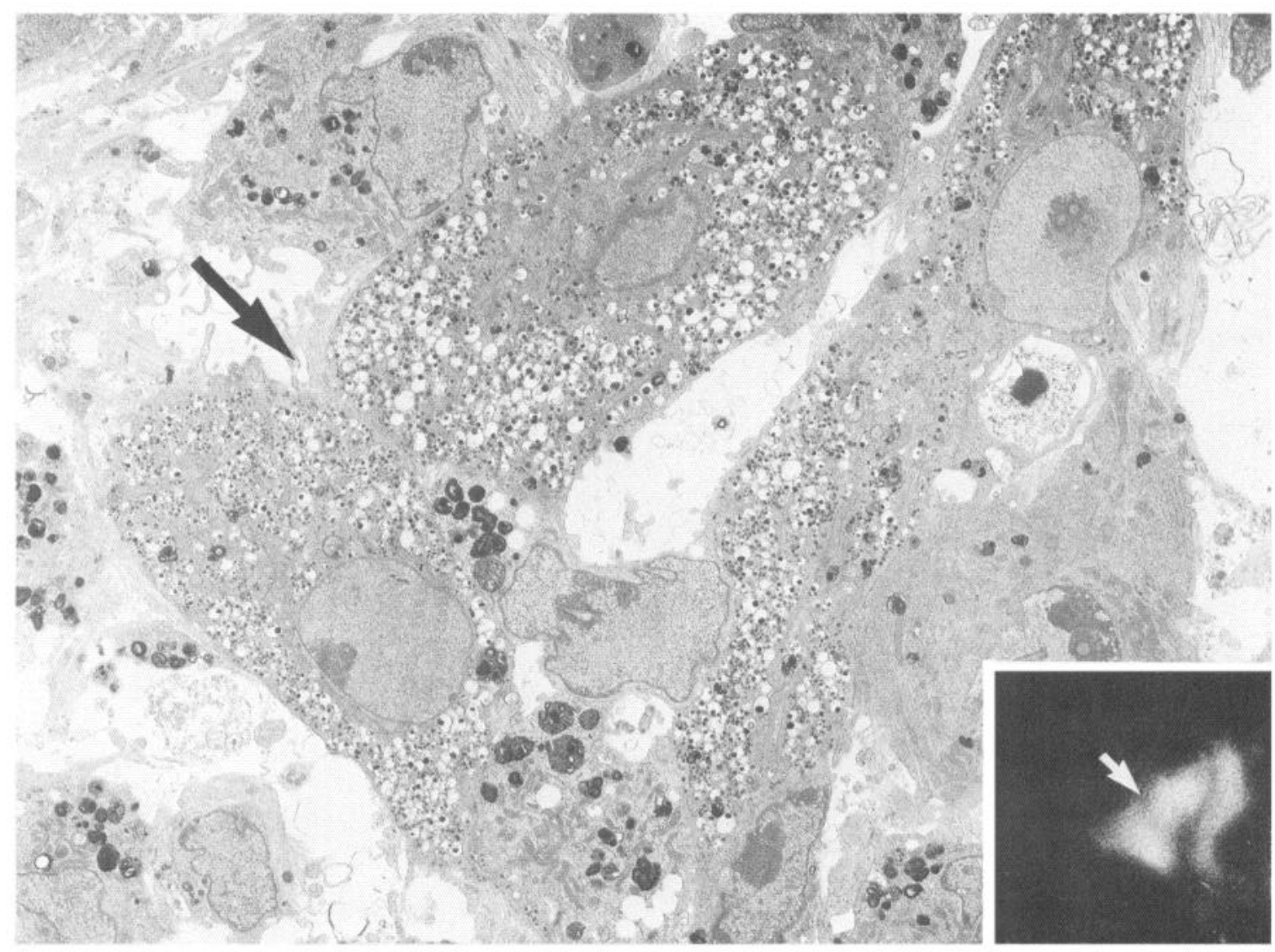

Figure 10. Correspondence of CA+ cells observed in the light microscope and GV-containing cells seen in the electron microscope. The inset shows $3 \mathrm{CA}+$ cells in a neural crest culture after $21 \mathrm{~d}$ in vitro. The electron micrograph shows that the same 3 cells contain abundant GV in their cytoplasm. The GV are absent from surrounding cells that are not $\mathrm{CA}+$. Arrows indicate the same relative position in both photographs. Magnification, light micrograph, $\times 475$; electron micrograph, $\times 3780$.

latter is acting in more subtle ways, such as by damaging nerve terminals.

\section{Ultrastructural correlates of $\mathrm{CA}+$ cell development}

Previous reports have described briefly the ultrastructural appearance of cells in neural crest cultures containing CA-storing dense core granules. These cells have variously been described as resembling "avian embryonic sympathetic neurons," "small, intensely fluorescent or chromaffin cells," "neuroblasts," or "developing chromaffin cells" (Cohen, 1977; Sieber-Blum and Cohen, 1980; Fauquet et al., 1981). In the present study we wished to analyze in more detail the ultrastructural properties of the $\mathrm{CA}+$ cells that developed in our neural crest cultures using correlative light-microscope histofluorescence and electron microscopy. The technique that we used for this purpose allowed us to detect CA + cells in cultures as young as $4 \mathrm{~d}$ and simultaneously provided excellent ultrastructural preservation for subsequent electron-microscopic analysis.

Absent in previous reports is a direct demonstration that the cells observed in the electron microscope correspond to the $\mathrm{CA}+$ cells observed in the light microscope. In the present study we have demonstrated this correspondence. Our data show that the $\mathrm{CA}+$ cells contain abundant GV in their cytoplasm. Such cells are not observed in regions of the culture that do not possess $\mathrm{CA}+$ cells. Although this result is perhaps not surprising, it provides the information necessary to allow comparison of data on $\mathrm{CA}+$ cells at the light level with data on the GV-containing cell population observed in the electron microscope.

One important question concerns the relationship of the $\mathrm{CA}+$ cells that develop in our neural crest cultures to the CA + cell types observed during in vivo development. During the development of the sympathetic ganglia of the chick, 2 types of CA+ cells can be seen that contain large dense core vesicles (Wechsler and Schmekel, 1967; Luckenbill-Edds and van Horn, 1980). One type is a sympathetic neuroblast that matures into a principal sympathetic neuron. The second type resembles the first, and contains somewhat larger $\mathrm{GV}$, but probably degenerates during the later stages of embryonic development (LuckenbillEdds and van Horn, 1980). SIF-like cells are either entirely absent or very infrequent in adult chicken paravertebral sympathetic ganglia, although such cells are present in the carotid body and extra-adrenal chromaffin tissue (Bennett and Malmfors, 1970; Luckenbill-Edds and van Horn, 1980). Chromaffin cells do develop in the avian adrenal gland and exhibit a morphology similar to that seen in other species (Unsicker, 1973).

Some CA + cells that resemble those that develop in our neural crest cultures have been observed in cultures of older avian embryonic sympathetic ganglia (Lever and Presley, 1971; Chamley et al., 1972; Eranko, 1972; Hervonen and Rechardt, 1972; Benitez et al., 1974; Hervonen, 1974, 1975; Jacobowitz and Greene, 1974). These cells probably correspond to cells observed in the electron microscope that contain abundant large, dense core vesicles $80-150 \mathrm{~nm}$ in diameter in their cytoplasm (Lever and Presley, 1971; Benitez et al., 1974; Hervonen and 


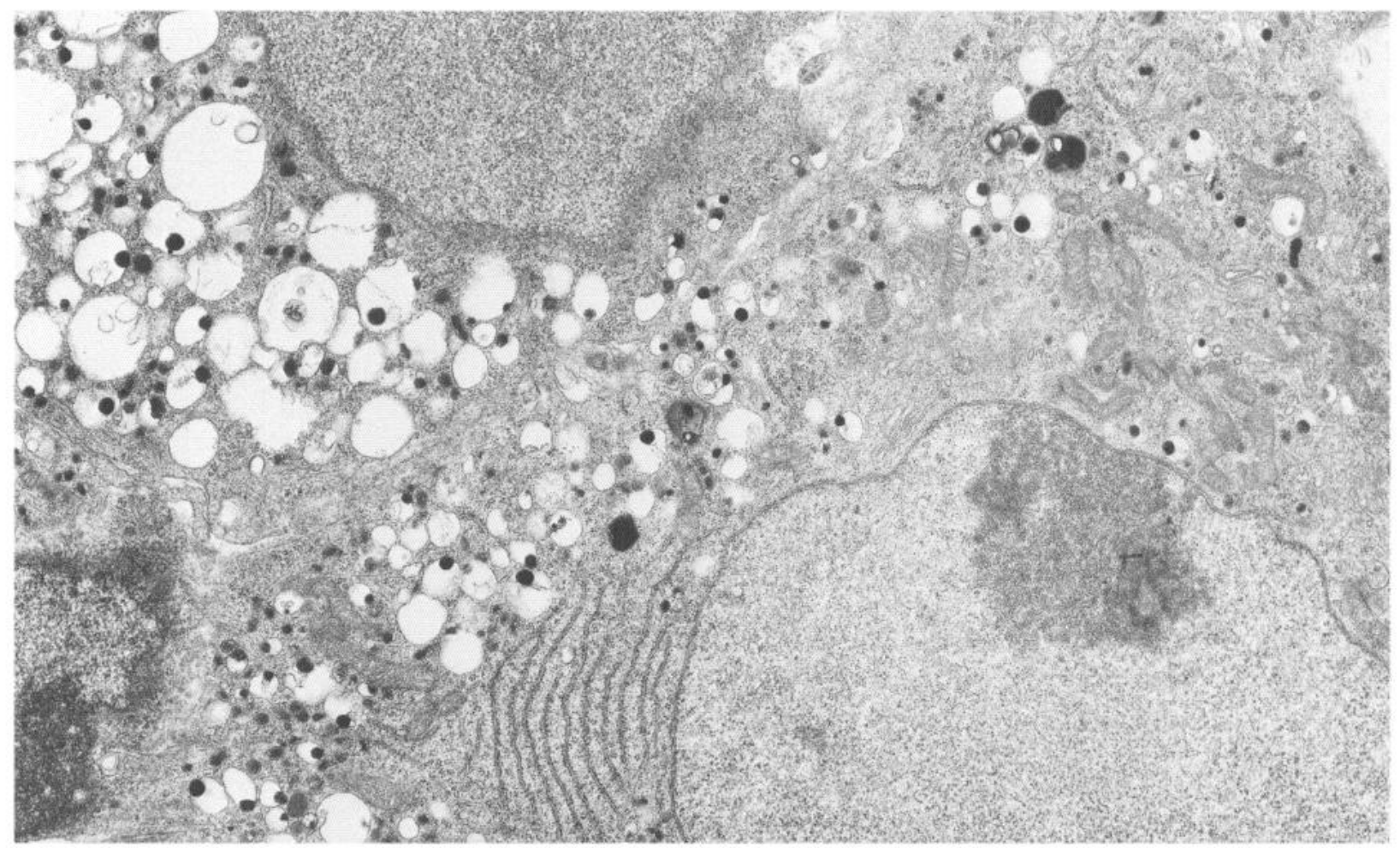

Figure 11. Ultrastructure of CA + cells after $14 \mathrm{~d}$ in vitro. Electron micrograph showing portions of 3 cells from a neural crest culture after $14 \mathrm{~d}$ in vitro, containing GV. The cell at the lower right also contains several Golgi figures, numerous mitochondria, rough endoplasmic reticulum, and free ribosomes. Magnification, $\times 11,250$.

Rechardt, 1974; Hervonen and Eranko, 1975). These cells persist in cultured ganglia in the absence of NGF. The identity of these cells has been determined differently by different authors. Lever and Presley (1971) suggested that they are analagous to "interneurons" (SIF cells) of the rat sympathetic ganglia (Matthews and Raisman, 1969). However, Benitez et al. $(1973,1974)$ concluded that many of these cells are actually young principal neurons because of their light-microscopic morphology. Hervonen and Eranko (1975) contended that they are sympathicoblasts and not SIF cells on the basis of the arrangement of the chromatin in the nucleus. Our observed modal GV diameters were similar to those of the vesicles present in the cytoplasm of adrenergic cells found in sclerotomal cultures initiated from 3-d-old quail embryos (Smith and Fauquet, 1984). Precise size comparisons are not possible because of differences in fixation and staining methods.

On the basis of our analysis, it seems that the $\mathrm{CA}+$ cells that differentiate in our quail neural crest cultures are morphologically similar to the cells with CA storage granules in their cytoplasm found in avian sympathetic ganglia in tissue culture and transiently during embryogenesis in vivo. They may be similar in phenotype to the first CA+ cells that are observed to develop in vivo as the primary sympathetic chains form (Enemar et al., 1965; Wechsler and Schmekel, 1967). In many respects these CA + cells resemble type I SIF cells. These cells with CA+ fluorescence in their cell body in neural crest cultures possess abundant $\mathrm{GV}$ with modal diameters near $100 \mathrm{~nm}$. On the basis of the unimodal nature of the histograms of GV diameter, it seems likely that we are dealing with a relatively homogeneous class of cells, at least with respect to their ultrastructural properties. The CA + cells in our cultures remain quite constant with regard to the size and density of GV present in the cytoplasm over a period of 3 weeks in vitro. As noted above, these CA+ cells also do not exhibit neurofilament immunoreactivity. In

Table 1. Ultrastructural properties of CA+ cells

\begin{tabular}{lllllll}
$\begin{array}{l}\text { Days } \text { in } \\
\text { vitro }\end{array}$ & $\begin{array}{l}\text { Observed } \\
\text { mean } \\
\text { GV diam }(\mathrm{nm})\end{array}$ & $\begin{array}{l}\text { Corrected } \\
\text { mean } \\
\text { GV diam } \\
(\mathrm{nm})\end{array}$ & $\begin{array}{l}\text { Observed } \\
\text { modal GV } \\
\text { diam }(\mathrm{nm})\end{array}$ & $\begin{array}{l}\text { GV with } \\
\text { observed } \\
\text { diameters } \\
>200 \mathrm{~nm}(\%)\end{array}$ & $\begin{array}{l}\text { Total no. of } \\
\text { GV analyzed }\end{array}$ & $\begin{array}{l}\text { Total } \\
\text { no. of } \\
\text { cells } \\
\text { analyzed }\end{array}$ \\
\hline 5 & $145 \pm 56$ & 172 & 105 & 19.4 & 500 & 15 \\
7 & $137 \pm 74$ & 145 & 85 & 12.4 & 410 & 28 \\
14 & $160 \pm 91$ & 174 & 115 & 17.1 & 410 & 45 \\
21 & $190 \pm 122$ & 219 & 85 & 33.0 & 376 & 27 \\
\hline
\end{tabular}

Observed mean GV diameter is expressed \pm SD for the total number of GV analyzed. The corrected mean GV diameter was calculated by the method of Giger and Riedwyl, as described in Weibel (1979). 


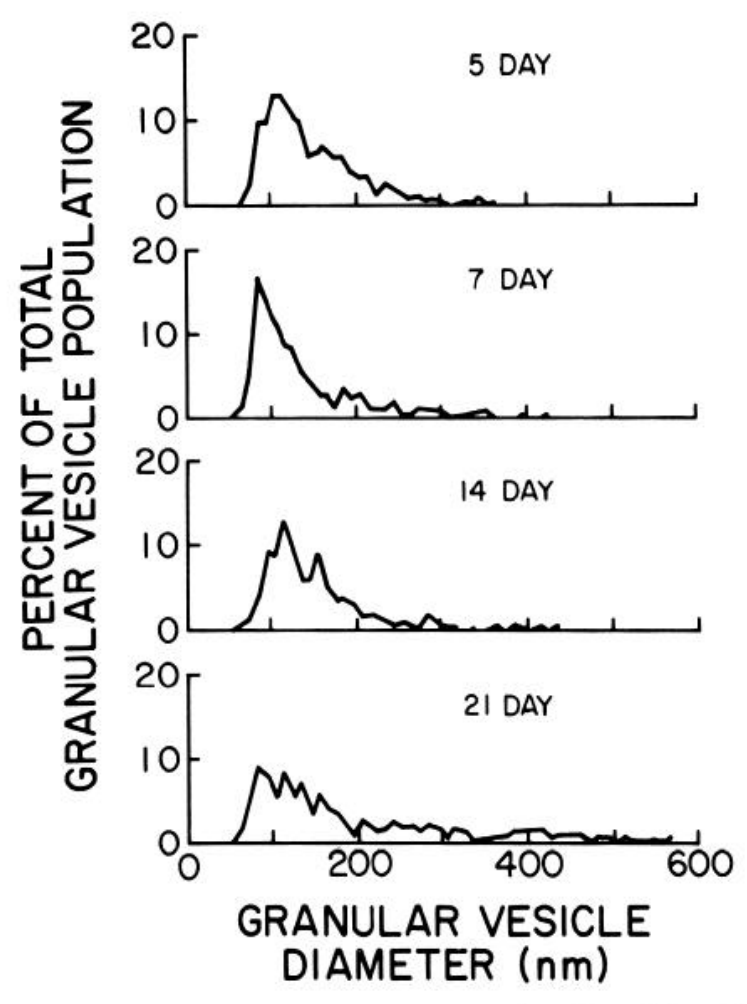

Figure 12. Histograms of GV diameters as a function of time in culture. Neural crest cultures were grown for $5,7,14$, and $21 \mathrm{~d}$ in vitro and then processed to reveal CA + cells in the light microscope, followed by electron microscopy and morphometry of GV diameters, as described in Materials and Methods. The percentage of GV with diameters that fell in a given bin $10 \mathrm{~nm}$ wide is shown.

contrast, the SIF-like cells observed in vivo probably either degenerate or are transformed into principal sympathetic neurons (Wechsler and Schmekel, 1967; Luckenbill-Edds and van Horn, 1980). Such a transformation can also occur when SIF-like cells from rat sympatheic ganglia or rat and chick adrenal chromaffin

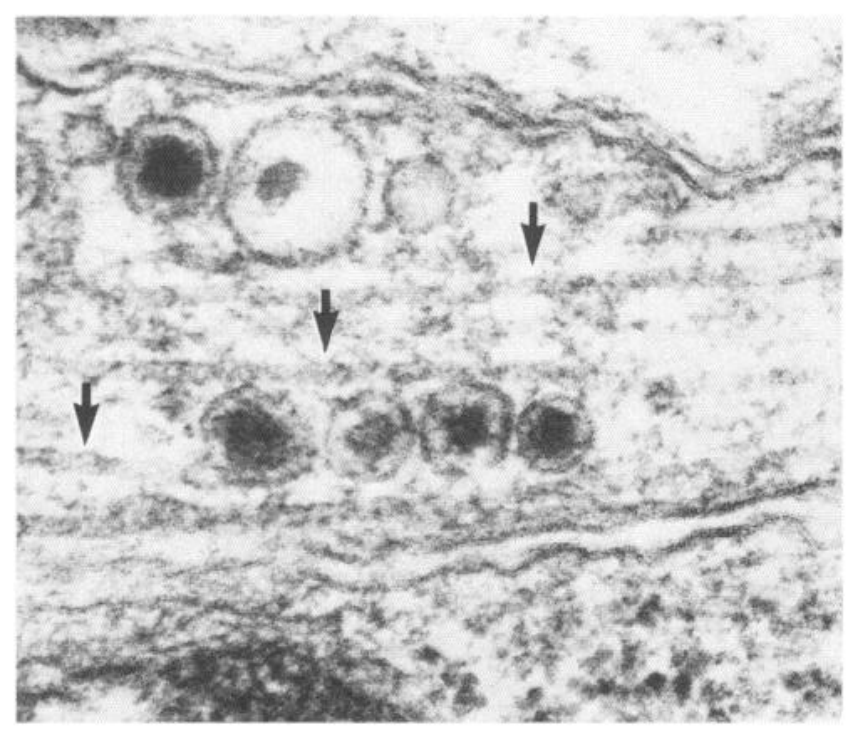

Figure 13. Presence of GV in cellular processes. Electron micrograph showing a segment of a neurite located in a cluster of GV-containing cells in a neural crest culture after $14 \mathrm{~d}$ in vitro. Large GV vesicles are aligned along an array of microtubules (arrows). Magnification, $\times 90,750$.

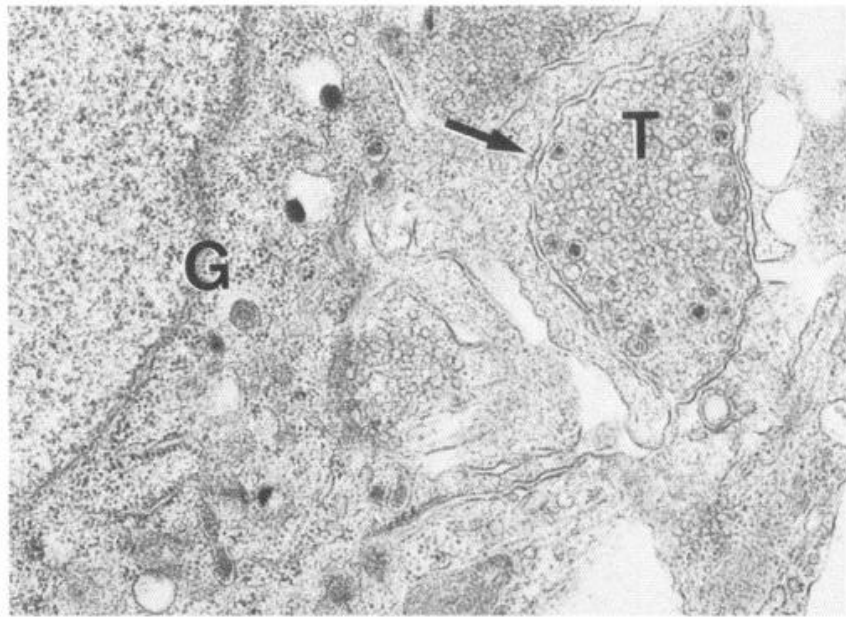

Figure 14. A nerve terminal contacting a GV-containing cell. A terminal profile $(T)$ in association with a granule-containing cell $(G)$ in a neural crest culture after $14 \mathrm{~d}$ in vitro. The terminal contains mostly small $(50 \mathrm{~nm})$ agranular vesicles and some larger $(100 \mathrm{~nm})$ granular vesicles, and rests in a depression in the granule-containing cell surface. A thickening (arrow) can be seen on the opposed membrane. Magnification, $\times 21,150$.

cells are grown under the appropriate conditions in tissue culture (Unsicker et al., 1978; Doupe et al., 1985a, b; Anderson and Axel, 1985, 1986; Shaw and Letourneau, 1986).

\section{$C A+$ cells in neural crest cultures and the adrenergic developmental program}

The available evidence, both at the light- and electron-microscopic levels, enables us to conclude that the CA + cells in our neural crest cultures possess a phenotype that in many aspects resembles that observed in SIF cells and that is intermediate between the adrenal chromaffin cell and principal sympathetic neuron phenotypes. This conclusion is based on several lines of evidence. The presence of CA clearly establishes that they are more differentiated than $\mathrm{CA}$ - progenitors of the neural crest. If these $\mathrm{CA}+$ cells were mature principal neurons, we would expect them to have CA fluorescence in processes, but not in cell bodies, to depend on NGF for survival and differentiation, to be neurofilament-positive, and to possess small GV in endings but not in the cell body. However, our findings of intense fluorescence in the cell body, the lack of prominent NGF and 6-hydroxydopamine responses, and the absence of neurofilament immunoreactivity, together with ultrastructural data, strongly argue against the CA + cells as being differentiated principal neuronlike cells. Largely on the basis of GV size and the presence of cellular processes, these $\mathrm{CA}+$ cells do not appear to be mature adrenal chromaffin cells. This, then, suggests that the CA+ cells that develop in our neural crest cultures either resemble SIFlike cells or a more primitive, sympathoadrenal precursor.

The difference between SIF-like cells and the postulated, more primitive, sympathoadrenal precursor cell is that the SIF cell is responsive to NGF and glucocorticoids, while the sympathoadrenal precursor is by definition not yet responsive to NGF or possibly to glucocorticoids (Landis and Patterson, 1981; Doupe et al., 1985b; Anderson and Axel, 1986). In the model of Landis and Patterson (1981) and Doupe et al. (1985b), we would expect SIF cells to be responsive to both NGF and glucocorticoids, although in very different ways. One would predict that in the 
presence of NGF, cell bodies would lose their intense CA fluorescence and would acquire other neuronal traits, such as the presence of neurofilaments and extension of long $\mathrm{CA}+$ processes. We have not systematically examined all of these traits in our neural crest cultures, but we do not see a loss of cell body fluorescence and the retention of a large number of CA fluorescent processes in the presence of exogenous NGF. One reservation is that the SIF cell conversions observed by Doupe et al. $(1985 \mathrm{a}, \mathrm{b})$ are quite slow, so that we simply may not have waited long enough for the transition to occur. However, it should be noted that the neuroendocrine precursor cell isolated by Anderson and Axel (1986) can show NGF or glucocorticoid responses within 3-4 d. One possible explanation is that the $\mathrm{CA}+$ cells in our cultures are prevented from undergoing further developmental changes because they lack exposure to some appropriate signal. For example, the cells may require interaction with somitic mesenchyme or target tissue to become competent to respond to NGF (Smith and Fauquet, 1984; Davies et al., 1987). Another point is that since our cells are grown in medium containing serum and embryo extract, perhaps the presence of glucocorticoids in the medium acts to mask any effect of exogenously added NGF (Unsicker et al., 1978). At present, we cannot distinguish among these possibilities.

It is also possible that the CA + cells that develop in our neural crest cultures are neither a sympathoadrenal precursor nor a SIF-like developmental intermediate, but are rather a differentiated endpoint cell type, such as the $\mathrm{CA}+$ cells found in the carotid body and extra-adrenal chromaffin tissue. This point will be resolved if conditions can be found that enable us to make the $\mathrm{CA}+$ cells in our neural crest cultures progress to another point in development, or if we can find additional phenotypic markers that further clarify the developmental status of these cells. It is also worth noting that there may be significant species differences with respect to the precise regulation of developmental pathways in the cell lineage of the autonomic nervous system (Edgar et al., 1981). Thus, not all aspects of the models generated from experiments using rodents necessarily apply to avian neuronal development.

\section{Conclusions}

In summary, our present light- and electron-microscopic data, together with previous results obtained by ourselves and others, indicate that the $\mathrm{CA}+$ cells that develop in our neural crest cultures resemble, in many respects, SIF-like cells. Under the conditions of our cultures, the CA + cell type seems quite stable for at least 3 weeks in vitro. As such, these cells offer excellent opportunities for future investigations concerning the mechanism by which neural crest cells acquire adrenergic traits and the specific cues necessary for them to execute additional steps in the adrenergic pathway of differentiation.

\section{References}

Aloe, L., E. Mugnaini, and R. Levi-Montalcini (1975) Light and electron microscope studies on the excessive growth of sympathetic ganglia in rats injected from birth with 60HDA and NGF. Arch. Ital. Biol. 113: 326-353.

Anderson, D. J., and R. Axel (1985) Molecular probes for the development and plasticity of ncural crest derivatives. Cell 42: 649-662.

Anderson, D. J., and R. Axel (1986) A bipotential neuroendocrine precursor whose choice of cell fate is determined by NGF and glucocorticoids. Cell 47: 1079-1090.

Angeletti, P. U., and R. Levi-Montalcini (1970) Sympathetic nerve cell destruction in newborn mammals by 6 -hydroxydopamine. Proc. Natl. Acad. Sci. USA 65: 114-121.
Barde, Y. A., D. Edgar, and H. Thoenen (1980) Sensory neurons in culture: Changing requirements for survival factors during embryonic development. Proc. Natl. Acad. Sci USA 77: 1199-1203.

Benitez, H. H., M. R. Murray, and L. J. Cote (1973) Responses of sympathetic chain-ganglia isolated in organotypic culture to agents affecting adrenergic neurons: Fluorescence histochemistry. Exp. Neurol. 39: 424-448.

Benitez, H. H., E. B. Masurovsky, and M. R. Murray (1974) Interneurons of the sympathetic ganglia in organotypic culture. A suggestion as to their function based on three types of study. J. Neurocytol. 3: 363-384.

Bennett, G. S., S. J. Tapscott, C. DiLullo, and H. Holtzer (1984) Differential binding of antibodies against the neurofilament triplet proteins in different avian neurons. Brain Res. 304: 291-302.

Bennett, T., and T. Malmfors (1970) The adrenergic nervous system of the the domestic fowl (Gallus domesticus L.). Z. Zellforsch. Mikrosk. Anat. 106: 22-50.

Bernd, P. (1985) Appearance of nerve growth factor receptors on cultured neural crest cells. Dev. Biol. 112: 145-156.

Bernd, P. (1986a) Presence and/or absence of nerve growth factor receptors on neuron-like cells in long term neural crest cultures. Soc. Neurosci. Abstr. 12: 1094.

Bernd, P. (1986b) Characterization of nerve growth factor binding to cultured neural crest cells: Evidence of an early developmental form of the NGF receptor. Dev. Biol. 115: 415-424.

Black, I. B. (1982) Stages of neurotransmitter development in autonomic neurons. Science 215: 1198-1204.

Biscoe, T. J. (1971) Carotid body: Structure and function. Physiol. Rev. 51: 437-495.

Bohn, M. C., J. A. Kessler, L. Golightly, and I. B. Black (1983) Appearance of enkephalin immunoreactivity in rat adrenal medulla following treatment with nicotinic antagonists or reserpine. Cell Tissue Res. 231: 469-479.

Burnstock, G., and M. Costa (1975) Adrenergic Neurons, Wiley, New York.

Cahn, R. D., H. G. Coon, and M. R. Cahn (1967) Cell culture and cloning techniques. In Methods in Developmental Biology, F. W. Wilt and N. K. Wessels, eds., pp. 493-530, Crowell, New York.

Chamley, J. H., G. E. Mark, G. R. Campbell, and G. Burnstock (1972) Sympathetic ganglia in culture I. Neurons. Z. Zellforsch. Mikrosk. Anat. 135: 287-314.

Cochard, P., and D. Paulin (1984) Initial expression of neurofilaments and vimentin in the central and peripheral nervous system of the mouse embryo in vivo. J. Neurosci. 4: 2080-2094

Cochard, P., M. Goldstein, and I. B. Black (1978) Ontogenetic appearance and disappearance of tyrosine hydroxylase and catecholamines in the rat embryo. Proc. Natl. Acad. Sci. USA 75: 2986-2990.

Cochard, P., M. Goldstein, and I. B. Black (1979) Initial development of the noradrenergic phenotype in autonomic neuroblasts of the rat embryo in vivo. Dev. Biol. 71: 100-114.

Cohen, A. M. (1972) Factors directing the expression of sympathetic nerve traits in cells of neural crest origin. J. Exp. Zool. 917: 167-182.

Cohen, A. M. (1977) Independent expression of the adrenergic phenotype by neural crest cells in vitro. Proc. Natl. Acad. Sci. USA 74: 2899-2903.

Cohen, A. M., and I. R. Konigsberg (1975) A clonal approach to the problem of neural crest determination. Dev. Biol. 46: 262-280.

Coupland, R. E. (1965) The Natural History of the Chromaffin Cell, Longman, New York.

Davies, A. M., C. Bandtlow, R. Heumann, S. Korsching, H. Rohrer, and $H$. Thoenen (1987) Timing and site of nerve growth factor synthesis in relation to innervation and expression of the receptor. Nature 326: 353-358.

Doupe, A. J., and P. H. Patterson (1980) Glucocorticoids and the developing nervous system. In Current Topics in Neuroendocrinology, D. Ganten and D. Pfaff, eds., pp. 23-43, Springer-Verlag, Berlin.

Doupe, A. J., S. C. Landis, and P. H. Patterson (1985a) Environmental influences in the development of neural crest derivatives: Glucocorticoids, growth factors, and chromaffin cell plasticity. J. Neurosci. 5: 2119-2142.

Doupe, A. J., P. H. Patterson, and S. C. Landis (1985b) Small intensely fluorescent cells in culture: Role of glucocorticoids and growth factors in their development and interconversions with other neural crest derivatives. J. Neurosci. 5: 2143-2160.

Edgar, D., Y. A. Barde, and H. Thoenen (1981) Subpopulations of 
cultured chick sympathetic neurons differ in their requirements for survival factors. Nature 289: 294-295.

Ehrmann, R. L., and G. O. Gey (1956) The growth of cells on a transparent gel of reconstituted rat-tail collagen. J. Natl. Cancer Inst. 16: 1375-1403.

End, D., L. Pevzner, A. Lloyd, and G. Guroff (1983) Identification of nerve growth factor receptors in primary cultures of chick neural crest cells. Dev. Brain Res. 7: 131-136.

Enemar, A., B. Flack, and R. Hakanson (1965) Observations on the appearance of norepinephrine in the sympathetic nervous system of the chick embryo. Dev. Biol. 11: 268-283.

Eranko, L. (1972) Ultrastructure of the developing sympathetic nerve cell and the storage of catecholamines. Brain Res. 46: 159-172.

Eranko, O. (ed.) (1975) Structure and function of the small, intensely fluorescent sympathetic cells. In Fogarty International Center Proceedings, United States Government Printing Office, Washington, D.C.

Fauquet, M., J. Smith, C. Ziller, and N. M. LeDouarin (1981) Differentiation of autonomic precursor cells in vitro: Cholinergic and adrenergic traits in cultured neural crest cells. J. Neurosci. l: 478492

Finch, L., G. Hausler, and H. Thoenen (1973) A comparison of the effects of chemical sympathectomy by 6-hydroxydopamine in newborn and adult rats. Br. J. Pharmacol. 47: 249-260.

Furness, J. B., M. Costa, and A. J. Wilson (1977) Water-stable fluorophores, produced by reaction with aldehyde solutions, for the histochemical localization of catechol- and indolcthylamincs. Histochemistry 52: 159-170.

Gabella, G. (1976) Structure of the Autonomic Nervous System, Chapman and Hall, London.

Garcia-Arraras, J. E., M. Chanconie, and J. E. Fontaine-Perus (1984) In vivo and in vitro development of somatostatin-like immunoreactivity in the peripheral nervous system of quail embryos. J. Neurosci. 4: $1549-1558$

Gotz, R., R. Meier, M. Becker-Andre, R. Heumann, and H. Thoenen (1986) Molecular cloning of bovine and chick nerve growth factor: Delineation of conserved and unconserved domains and their relationship to biological activity and antigenicity. Soc. Neurosci. Abstr. 12: 214.

Greene, L. A. (1977a) Quantitative in vitro studies on the nerve growth factor (NGF) requirement of neurons. I. Sympathetic neurons. Dev. Biol. 58: 96-105.

Greene, L. A. (1977b) Quantitative in vitro studies on the nerve growth factor (NGF) requirement of neurons. II. Sensory neurons. Dev. Biol. 58: 106-113.

Greene, L. A., and G. Rein (1977) Release, storage and uptake of catecholamines by a clonal cell line of nerve growth factor (NGF) responsive pheochromocytoma cells. Brain Res. 129: 247-263.

Greene, L. A., and E. M. Shooter (1980) The nerve growth factor: Biochemistry, synthesis and mechanism of action. Annu. Rev. Neurosci. 3: 353-402.

Greiner, C. A. M., and G. Guroff (1986) Most catecholamine-containing neural crest cells lack NGF receptors. Soc. Neurosci. Abstr. 12: 1094 .

Greiner, C. A. M., A. T. Lloyd, and G. Guroff (1985) Developmental expression of nerve growth factor receptors in primary cultures of neural crest cells. Soc. Neurosci. Abstr. 11:937.

Greiner, C. A., A. T. Lloyd, and G. Guroff (1986) Ontogeny of the nerve growth factor receptor in primary cultures of neural crest cells. Brain Res. 391: 145-150.

Grillo, M. A. (1966) Electron microscopy of sympathetic tissues. Pharmacol. Rev. 18: 387-399.

Grillo, M. A., L. Jacobs, and J. H. Comroe, Jr. (1974) A combined fluorescence histochemical and electron microscopic method for studying special monoamine-containing cells (SIF cells). J. Comp. Neurol. 153: 1-14.

Hervonen, H. (1974) Formaldehyde-induced fluorescence in the sympathetic ganglia of the chick embryo in maturing organotypic culture. Med. Biol. 52: 154-163.

Hervonen, H. (1975) Differentiation of sympathicoblasts in cultures of chick ganglia. Anat. Embryol. 146: 225-243.

I lervonen, H., and O. Eranko (1975) Fluorescence histochemical and electron microscopical observations on sympathetic ganglia of the chick embryo cultured with and without hydrocortisone. Cell Tissue Res. 156: 145-166.
Hervonen, H., and L. Rechardt (1972) Formaldehyde-induced fluorescence (FIF) in the sympathetic ganglia of chick embryos in tissue culture. Scand. J. Clin. Lab. Invest. (Suppl. 122) 29: 69.

Hervonen, H., and L. Rechardt (1974) Light and electron microscopic demonstration of cholinesterases of the cultured sympathetic ganglia of the chick embryo. Histochemistry 39: 129-142.

Howard, M. J., and M. Bronner-Fraser (1986) Neural tube-derived factors influence differentiation of neural crest cells in vitro: Effects on activity of neurotransmitter biosynthetic enzymes. Dev. Biol. 117: 45-54.

Iversen, L. L. (1967) The Uptake and Storage of Noradrenaline in Sympathetic Nerves, Cambridge U. P., Cambridge.

Jacobowitz, D. M., and L. A. Greene (1974) Histofluorescence study of chromaffin cells in dissociated cell cultures of chick embryo sympathetic ganglia. J. Neurobiol. 5: 65-83.

Jacobs, M., Q. L. Choo, and C. Thomas (1982) Vimentin and $70 \mathrm{~K}$ neurofilament protein co-exist in embryonic neurons from spinal ganglia. J. Neurochem. 38: 969-977.

Johnson, G. D., R. S. Davison, K. C. McNamee, G. Russell, D. Goodwin, and E. J. Holborow (1982) Fading of immunofluorescence during microscopy: A study of the phenomenon and its remedy. J. Immunol. Methods 55: 231-242.

Jonakait, G. M., K. Markey, M. Goldstein, and I. B. Black (1984) Transient expression of selected catecholaminergic traits in cranial sensory and dorsal root ganglia in the embryonic rat. Dev. Biol. 101. $51-60$.

Kahn, C. R., and M. Sieber-Blum (1983) Cultured quail neural crest cells attain competence for terminal differentiation into melanocytes before competence for terminal differentiation into adrenergic neurons. Dev. Biol. 95: 232-238.

Kahn, C. R., J. T. Coyle, and A. M. Cohen (1980) Head and trunk neural crest in vitro: Autonomic neuron differentiation. Dev. Biol. 77: $340-348$.

Kessler, J. A. (1985) Differential regulation of peptide and catecholamine characteristics in cultured sympathetic neurons. Neuroscience 15: 827-839.

Kirby, M. L., and S. A. Gilmore (1976) A correlative histofluorescence and light microscopic study of the formation of the sympathetic trunks in chick embryos. Anat. Rec. 186: 437-450.

Landis, S. C., and P. H. Patterson (1981) Neural crest cell lineages. Trends Neurosci. 4: 172-175.

LeDouarin, N. M. (1982) The Neural Crest, Cambridge U. P., Cambridge.

Lee, V. M.-Y., and C. Page (1984) The dynamics of nerve growth factor-induced neurofilament and vimentin filament expression and organization in PC12 cells. J. Neurosci. 4: 1701-1714.

Lever, J. D., and M. Presley (1971) Studies on the sympathetic neurone in vitro. Prog. Brain Res. 34: 499-512.

Levi-Montalcini, R,. and L. Aloe (1980) Tropic, trophic, and transforming effects of nerve growth factor. Adv. Biochem. Psychopharmacol. 25: 3-15.

Levi-Montalcini, R., and P. U. Angeletti (1968) Nerve growth factor. Physiol. Rev. 48: 534-569.

Luckenbill-Edds, L., and C. van Horn (1980) Development of chick paravertebral sympathetic ganglia I. Fine structure and correlative histofluorescence of catecholaminergic cells. J. Comp. Neurol. 191: $65-76$.

Mackey, H. M., R. F. Payelte, and M. D. Gershon (1986) Expression of serotonin, tyrosine hydroxylase and GABA in cultures of neurogenic cells from neural crest and branchial arches: Effect of addition of the bowel. Soc. Neurosci. Abstr. 12: 1111.

Mains, R. E., and P. H. Patterson (1973) Primary cultures of dissociated sympathetic neurons I. Establishment of long term growth in culture and studies of differentiated properties. J. Cell Biol. 59: 329345.

Mascorro, J. A., and R. D. Yates (1980) Paraneurons and paraganglia: Histological and ultrastructural comparisons between intraganglion paraneurons and extradrenal paraganglion cells. Adv. Biochem. Psychopharmacol. 25: 201-214.

Matthews, M. R., and G. Raisman (1969) The ultrastructure and somatic efferent synapses of small granule-containing cells in the superior cervical ganglion. J. Anat. 105: 255-282.

Maxwell, G. D., and D. S. Christie (1986) Properties of catcholaminepositive cells which differentiate in neural crest cultures. Soc. Neurosci. Abstr. 12: 1124. 
Maxwell, G. D., and P. D. Sietz (1983) Expression of the capacity to release $\left[{ }^{3} \mathrm{H}\right]$ norepinephrine by neural crest cultures. J. Neurosci. 3 : 1860-1867.

Maxwell, G. D., and P. D. Sietz (1985) Development of cells containing catecholamines and somatostatin-like immunoreactivity: $\mathrm{Re}-$ lationship of DNA synthesis to phenotypic expression. Dev. Biol. 108: 203-209.

Maxwell, G. D., P. D. Sietz, and C. E. Rafford (1982) Synthesis and accumulation of putative neurotransmitters by cultured neural crest cells. J. Neurosci. 2: 879-888.

Maxwell, G. D., P. D. Sietz, and S. Jean (1984a) Somatostatin-like immunoreactivity is expressed in neural crest cultures. Dev. Biol. 101: $357-366$

Maxwell, G. D., P. D. Sietz, and P. H. Chenard (1984b) Development of somatostatin-like immunoreactivity in embryonic sympathetic ganglia. J. Neurosci. 4: 576-584.

Noden, D. M. (1978) Interactions directing the migration and cytodifferentiation of avian neural crest cells. In Specificity of Embryological Interactions, D. Garrod, ed., pp. 5-49, Chapman and Hall, London.

Norr, S. (1973) In vitro analysis of sympathetic neuron differentiation from chick neural crest cells. Dev. Biol. 34: 16-38.

Oliver, D. L. (1985) Quantitative analyses of axonal endings in the central nucleus of the inferior colliculus and distribution of ${ }^{3} \mathrm{H}-\mathrm{la}$ beling after injections in the dorsal horn of the cochlear nucleus. J. Comp. Neurol. 237: 343-359.

Partlow, L. M., and M. G. Larrabee (1971) Effects of nerve-growth factor, embryo age and metabolic inhibitors on growth of fibers and on synthesis of ribonucleic acid and protein in embryonic sympathetic ganglia. J. Neurochem. 18: 2101-2118.

Patterson, P. H., L. F. Reichardt, and L. Y. Chun (1975) Biochemical studies on the development of primary sympathetic neurons in cell culture. Cold Spring Harbor Symp. Quant. Biol. 40: 389-398.

Payette, R. F., G.S. Bennett, and M. D. Gershon (1984) Neurofilament expression in vagal neural crest-derived precursors of enteric neurons. Dev. Biol. 105: 273-287.

Price, J., and A. W. Mudge (1983) A subpopulation of rat dorsal root ganglion neurons is catecholaminergic. Nature 304: 241-243.

Rothman, T. P., M. D. Gershon, and H. Holtzer (1978) The relationship of cell division to the acquisition of adrenergic characteristics by developing sympathetic ganglion cell precursors. Dev. Biol. 65 . 322-341.

Shaw, T. J., and P. C. Letourneau (1986) Chromaffin cell heterogeneity of process formation and neuropeptide content under control and nerve growth factor altered conditions in cultures of chick embryonic adrenal gland. J. Neurosci. Res. 16: 337-355.

Shelton, D. L., L. F. Reichardt, and E. M. Shooter (1986) Isolation and sequencing of a clone of chicken genomic DNA encoding a protein highly homologous to mouse beta nerve growth factor. Soc. Neurosci. Abstr. 12: 1095.

Sieber-Blum, M. (1984) Fibronectin-regulated methionine enkephalin-like and somatostatin-like immunoreactivity in quail neural crest cell cultures. Neuropeptides 4: 457-466.

Sieber-Blum, M., and A. M. Cohen (1980) Clonal analysis of quail neural crest cells: They are pluripotent and differentiate in vitro in the absence of non-neural crest cells. Dev. Biol. 80:96-106.

Sieber-Blum, M. S. R. Patel, and D. A. Riley (1986) In vitro differentiation of quail neural crest cells into sensory-like neuroblasts. Soc. Neurosci. Abstr. 12: 768.

Smith, J., and M. Fauquet (1984) Glucocorticoids stimulate adrenergic differentiation in cultures of migrating and premigratory neural crest. J. Neurosci. 4: 2160-2172.

Tapscott, S. J., G. S. Bennett, and H. Holtzer (1981) Neuronal precursor cells in the chick neural tube express neurofilament proteins. Nature 292: 836-838.

Taxi, J. (1979) The chromaffin and chromaffin-like cells in the autonomic nervous system. Int. Rev. Cytol. 57: 283-343.

Taxi, J., M. Derer, and A. Domici (1983) Morphology and histophysiology of SIF cells in the autonomic ganglia. In Autonomic Ganglia, L. Elfvin, ed., pp. 67-95, Wiley, Chichester, UK.

Teitelman, G., T. H. Joh, and D. J. Reis (1978) Transient expression of a noradrenergic phenotype in cells of the rat embryonic gut. Brain Res. 158: 229-234.

Teitelman, G., H. Baker, T. H. Joh, and D. J. Reis (1979) Appearance of catecholamine-synthesizing enzymes during development of rat sympathetic nervous system: Possible role of tissue environment. Proc. Natl. Acad. Sci. USA 76: 509-513.

Thoenen, H., and Y. A. Barde (1980) Physiology of nerve growth factor. Physiol. Rev. 60: 1284-1335.

Thoenen, H., and J. P. Tranzer (1968) Chemical sympathectomy by selective destruction of adrenergic nerve endings with 6-hydroxydopamine. Naunyn-Schmiedebergs Arch. Pathol. 261: 271-288.

Tranzer, J. P., and H. Thoenen (1968) An electron microscopic study of selective, acute degeneration of sympathetic nerve terminals after administration of 6-hydroxydopamine. Experientia 24: 155-156.

Unsicker, K. (1973) Fine structure and innervation of the avian adrenal gland I. Fine structure and innervation of the adrenal chromaffin cells and ganglion cell. Z. Zellforsch. Mikrosk. Anat. 145: 389-416.

Unsicker, K., B. Krisch, U. Otten, and H. Thoenen (1978) Nerve growth factor-induced fiber outgrowth from isolated rat adrenal chromaffin cells: Impairment by glucocorticoids. Proc. Natl. Acad. Sci. USA 75: 3498-3502.

Weber, K., G. Shaw, M. Osborn, E. Debus, and N. Geisler (1983) Neurofilaments, a subclass of intermediate filaments: Structure and expression. Cold Spring Harbor Symp. Quant. Biol. 48: 717-729.

Wechsler, W., and L. Schmekel (1967) Elektronenmikroskopische Untersuchung der Entwicklung der vegetativen (Grenzstrang-) und spinalen Ganglien bei Gallus domesticus. Acta Neuroveg. 30: 427-444.

Weibel, E. R. (1979) Stereological Methods, Academic, London.

Weston, J. A. (1970) The migration and differentiation of neural crest cells. Adv, Morphog. 8:41-114.

Wilson, S. P., K.-J. Chang, and O. H. Viveros (1980) Synthesis of enkephalins by adrenal medullary chromaffin cells: Reserpine increased incorporation of radiolabeled amino acids. Proc. Natl. Acad Sci. USA 77: $4364-4368$.

Wilson, S. P., M. M. Abou-Donia, K.-J. Chang, and O. H. Viveros (1981) Reserpine increases opiate-like peptide content and tyrosine hydroxylase activity in adrenal medullary chromaffin cells in culture. Neuroscience $6: 71-79$

Winick, M., and R. E. Greenberg (1965) Chemical control of sensory ganglia during a critical period of development. Nature 205: 180181

Zacchei, A. M. (1961) Lo sviluppo embrionale della quaglia giapponese (Couturnix couturnix japonica T. e S.). Arch. Ital. Anat. Embriol. $66: 36-62$.

Ziller, C., E. Dupin, P. Brazeau, D. Paulin, and N. M. LeDouarin (1983) Early segregation of a neuronal precursor cell line in the neural crest as revealed by culture in a chemically defined medium. Cell 32: 627638 